\title{
Julian Kałowski
}

\section{"Norma vitae" : pierwsze konstytucje zakonu marianów}

Prawo Kanoniczne : kwartalnik prawno-historyczny 26/3-4, 113-162

1983

Artykuł został zdigitalizowany i opracowany do udostępnienia w internecie przez Muzeum Historii Polski w ramach prac podejmowanych na rzecz zapewnienia otwartego, powszechnego i trwałego dostępu do polskiego dorobku naukowego i kulturalnego. Artykuł jest umieszczony w kolekcji cyfrowej bazhum.muzhp.pl, gromadzącej zawartość polskich czasopism humanistycznych i społecznych.

Tekst jest udostępniony do wykorzystania w ramach dozwolonego użytku. 


\section{"NORMA VITAE" \\ PIERWSZE KONSTYTUCJE ZAKONU MARIANOW}

Treśc: Wstęp. - I. Charakter prawny zakonu marianów, - II. Cel ogólny i szczegółowy zakonu marianów. - III. Srodki do osiągnięcia celów. - IV. Rady ewangeliczne. 1. Posłuszeństwo. 2. Ubóstwo. 3. Czystość. - V. Praktyki pobożne. - VI. Dyscyplina zakonna. 1. Umartwienia. 2. Posty. 3. Ubiór. 4. Skupienie i milczenie. 5. Studium. 6. Klauzura. 7. Kapitula win. 8. Biczowanie. - VII. Organizacja i zarząd. 1. Ustanawianie przelożonych. 2. Obowiązki przelożonych. VIII. Przyjęcie do zakonu, formacja i usuwamie. - IX. Zatwierdzenie „Norma vitae". - Zakończenie.

\section{Wstęp}

Pomimo to, że Polstka oficjalnie pnzyjęla chrześcijaństwo w dziesiątym wieku, to jednak jest rzeczą charakterystyczną, iż kraj nasz przez wieki nie zdobył się na stworzenie zakonu rdzennie polskiego. Wprawdzie w Polsce bujnie rozwijalło się życie zakonne, ale przenikało ono z Europy Zachodniej, a zwlaszcza z Italii.

Niektórzy z Polaków chcieli założyć zakon rdzennie polski, ale wszelkie ich usiłowania w tej dziedzinie nie przyniosły widocznych sikutików. Dopiero od XV wieku rozpoczyna się w Polsce nieznaczna działalność zakonodawcza. Powstają takie zgromadzenia, jak siostry bernardynki, augustianiki, siositry zgromadzenia Maryi Panny czyli prezentki oraz siostry życia Maryi.

Spośród zaś zakonów męskich wymienić nalė̇y zakon marianów. Założył go w 1673 r. były pijar, o. Stanisław Papczyński. Założonemu przez sielbie zakonowi Papczyński wyznaczył cel oraz środiki konieczne do jego osiągnięcia. $Z$ ogólnych zaś zasad prawa oraz mauki o spoleczeństwie wiemy, iż żadna instytucja nie może istnieć bez norm prawnych. Dlatego i Papiczyński przepisał marianom zasady, według których mieli oni postępować i naidal im tytuł Norma vitae, która jest zasadniczym aktem prawnym regulującym życie pierwszych marianów.

$Z$ tej więc racji, że Norma vitae 1 jest pierwszym zbiorem ustaw

\footnotetext{
1 Pelny tytul egzemplarza znajdującego się w Archiwum Diecezjalnym w Lublinie, syg. ALIX brzmi: Norma vitae religiosae Congregationi B. V. Mariae sine labe Conceptae Eremitarum Marianorum fidelibus defunctis praecipue militibus et peste sublatis suffragantium proposita et $a b$ Reverendissimo Domino Domino Lucio Cardinali Col- 
prawnych, przeznaczonych dla członków jednego z rdzennie polskich zakonów męskich, dokrument ten zasługuje na specjalne omówienie.

Należy nadto zaznaczyć, iż Norma vitae nie tylko nie jest znana, ale dotychiczas nie doczekała się żadnego opracowania. Wiprawdzie, jak podaje Estreicher, Norma vitae miała być drukowana ow 1687 r. ${ }^{2}$, ale $w$ obecnym stamie badan nie natrafiono na żaden jej drukowany egzemplarz. Odpisy zaś Norma vitae aiktualnie przechowywane są w dwóch miejscach, tj. w Archiwum Diecezjalnym w Luiblinie pod syg. AiLIX oraz w Portugalii $w$ Archiwum idella Camera Municipal Villa Real. Pomiędzy jednym a drugim egzemplarzem zachodza tylko małe różnice, kktóre bynajmniej nie świaldczą o różnorodności treści. Egzemplarz znajduljący się w Lublinie ma ponadto wstęp zaltytulowany: Praefatio informatoria. Celem jego jest określenie charakteru prawnego zakonu marianów.

Dopiero $z$ okazji prowadzenia procesu tbeatyfikacyjnego o. Stanisława Papczyńskiego, założyciela zakonu marianów, Norma vitae zamieszczono w 1977. $\mathrm{r}$. 'w pozyciji przygotowanej dla Komisji Historycznej Kongregacji dla Spraw Swiętych ${ }^{3}$.

Co się tyczy autoristwa Norma vitae to od początku istnienia zakonu marianów zawsze urważano, iż twórcą tego dokumentu jest o. Stanisław Papczyński, założyciel i pienwszy prawodawca tegoz zakonu. Natomiast przy obeenym stanie badań nie moźna podać ani daty jej napisania ani ostatecznego zredagowania. Norma vitae skłarda się z dziewięciu rozdziałów, w których autor porusza istotne zagadnienia konieczne do prowadzenia życia wedlug rad ewangelicznych.

W niniejszym artykule przeprowadza się analizę poszczególnych przepisów prawnych obowiązujących pierwszych marianów. Zostaną takize scharakteryzowane głowne instytukje zakonne oraz w miarę możliwości podjęte będą próby dojścia do pierwotnych źródel, $z$ których antor kkorzystał lub mógl korzyistać przy ukladamiu Norma vitae.

leredo ex commissione Sacrae Congregationis Regularium et Episcoporum correcta, Romae 1694. № 32 productum iudicialiter die 16 martii 1773 Franciscus Groszkowski, notarius; Tytuł zaś egzemplarza przechowywanego $w$ Portugalii $w$ Archiwum della Camera Municipal Villa Real jest następujący: Norma vitae Clericorum Recollectorum Immaculatae Conceptionis Beatissimae Virginis Mariae alias Marianorum animabus purgatorii suffragantium in Regno Poloniae.

2 K. Estreicher, Bibliografia polska, t. 32, Kraków 1938, s. 486.

3 Posnanien. Beatificationis et canonizationis Servi Dei Stanislai a Iesu Maria Papczyński fundatoris Clericorum Regularium Immaculatae Conceptionis B. M. V. (†1701), Positio super introductione causae et super virtutibus ex officio conncinata, Roma 1977, s. $460-482$. 


\section{Charakteı prawny zakonu marianów}

Każdy instytut zakonny należy do jednej $z$ uznanych i zatwierdzonych w ciągu wieków przez Kościól grup realizacji rad ewanglicznych. Odnośnie do istnienia różnych sposobów realizacji rad ewangelicznych czyli istnienia wielu form życia zalkonnego, Sołbór Watykański II pisze co następuje: „Sama zaś władza Kościoła pod przewodnictwem Ducha Świętego zatroszczyła się o to, aby je thumaczyć, praktykowaniem ich kierować a nadto ustanawiać stałe, trwałe formy życia na radach tych oparte. Stąd téz wyrosły niby na drzewie, które się cudownie i bujnie rozkrzewiło na roli Pańskiej z danego przez Boga zalążka, rozmaite formy życia samotnego lub wspólnego, rozmaite rodziny zakonne..." 4.

Ponieważ zaś w Kościele znane są różne formy życia konsekrowanego Bogu, dlatego obecnie zostanie rozpatrzony problem charakteru prawnego instytutu zorganizowanego przez o. Stanislawa Papczyńskiego. Podjęte zostaną zatem próby rozwiązania zagadnienia, czy o. Papczyński zamierzał założyć zakon kontemplacyjny, czynny, klerycki, laicki, żebrzący, kontemplacyjno-czynny, czy może jeszcze jakiś inny rodzaj zakonu. Zagadnienie to będzie rozważane w oparciu o wprowadzenie do Norma vitae, czyli o Praefatio informatoria. Ponadto przy rozwiązywaniu tej kwestii wykorzystane zostana wytyczne prawa dekretałów. Zastosowanie takiej metody wydaje się konieczne i $z$ tego względu, iz tylko w świetle obowiązującego w XVII wieku prawa kościelnego, lepiej można będzie naświetlić, a także zrozumieć niektóre kwestie odmoszące sie zarówno do początków, jak i do charakteru prawnego zakonu marianów.

Jest rzeczą godną uwagi, iz we wstępie do Norma vitae stwierdzono, że Zgromadzenie Niepokalanego Poczęcia istniejące ,in statu eremitico" kanonicznie erygowal Stefan Wierzbowski, biskup poznański i nominat archidiecezji gnieźnieńsikiej. Papież zaś Innocenty XI w 1681 r. obdarzył zgromadzenie marianów takimi odpustami, jakie przysługują każdej konfraterni. W roku 1677 król polski, Jan III Sobieski na sejmie w Warszawie nie tylko udzielił zakonowi marianów królewskiego zatwierdzenia, lecz także wziął go pod swój szczególny patronat 5 .

Nasuwa się zatem pytanie co znaczy wyrażenie zamieszczone $\mathrm{w}$ Norma vitae: "Congregationem Immaculatae Conceptionis in statu eremitico... Antistiti Stephano Wierzbowio, Posnaniensi Episcopo, et No-

“Konstytucja dogmatyczna o Kościele „Lumen gentium”, n. 43, Sobór Watykański II, Konstytucje, dekrety, deklaracje, Poznań 1968, S. 149.

5 Norma vitae "Praefatio informatoria", 1. 
minato Archiepiscopo Guesnensi... cannonice erigere" 6 .

$\mathrm{Z}$ historii życia zakonnego wiadomo, że eremityzm był jedną z juz nieistniejących, przynajmniej w Kościele zachodnim, form realizacji rad ewangelicznych. Słowo zaś „eremita” znaczy tyle co pustelnik, a zatem czlowiek oddający się życiu samotnemu-pulstelniczemu 7. Eremite zawsze przeciwstawiano cenobicie ${ }^{8}$.

Na Wschodzie zaś eremitą nazywano ascetę lub mnicha, który ży na pustyni, przebywał na osobności i prowadził życie wedlug zwyczajów albo norm przekazanych przez tradycję ${ }^{9}$. Natomiast w starożytności chrześcijańskiej termin ,eremita” oznaczał oddzielenie się od wpływów świata, prostotę serca i zjednoczenie z Bogiem 10 .

Zatem życie eremickie, zgodnie z pierwotnyrni założeniami, znaczylo tyle co życie pustelnicze, lub przebywanie w eremie, a eremici nie posiadali organizacji centralnej, nie prowadzili życia wspólnego i nie cieszyli się przywilejami przysługującymi duchownym 11 . A może w XVII wielku. wyrazenie, in statu e r emitico" milato inne znaczenie, niż mu pierwotnie nadawano?

Odpowiedzi na to pytanie należy doszukiwać się $w$ praikityce kościelnej, która w owym czasie (XVII wiek) nie uznawała za stan kanoniczny eremitów, nie podporzadkowanych wladzy przelożonych i żyjących samotnie. Władza więc kościelna za stan kanoniczny uznawała zrzeszenie osób żyjących wspólnie w jakimś instytucie zakonnym, zatwierdzonym przez prawowitą władzę kościelną, i pozostajacych pod zwierzchnictwem odnośnych przełożonych.

Skoro zatem w przedmowie do Norma vitae na określenie charakteru prawnego zakonu marianów użyto wyrażenia ,in statu eremitico" i skomo zaznaczono, że zgromadzenie marianów w takim właśnie stanie kanonicznie erygował biskup Wierzbowski, to $z$ konieczności wyrażeniu temu nadawano inne, a nie klasyczne znaczenie.

Nadto za słusznością powyższego rozumowania przemawia wy-

6 Tamże.

'J. P. Müller, Monaco, uso del termine nella Chiesa latina, Dizionario degli istituti di perfezione, vol. VI, Roma 1980, kol. 45; Por. C. XVI, q. 1, c. $1,8$.

\&. Gribomont, Eremita, Dizionario degli istituti di perfezione, vol. III, Roma 1976, kol. 1153.

${ }^{9} \mathrm{~J}$. R e záč, Eremita in Oriente, Dizionario degli istituti di perfezione, vol. III, jw., kol. 1153.

10 J. Gribomont, Eremita, jw.; Tenże, Mon a co, Dizionario degli istituti di perfezione, vol. VI, kol. 44; Por. C. XVI, q. 1, c. $1,8$.

${ }_{11} \mathrm{~F}$. Cespedes, Tractatus de exemptione regularium, Venetiis 1647, s. 560; L. De Franchis, Controversiae inter episcopos et reguiares, Romae 1656, s. 494 ; P. F a g n a n u s, Commentaria, lib. II, Coloniae Agrippinae 1681, s. 49. 
rażenie zamieszczone w Norma vitae, wedlug którego marianie jako eremici będą uzależnieni od władzy jednego przełożonego. A eremici zaś, jako że żyli pojedynczo, nie podlegali wladzy przełożonych.

$Z$ tego możemy wyciagnąć wniosek, iż termin „er emita", ,s't atus eremiticus", mie był terminem jednoznacanym. Za takim twierdzeniem opowiadają się cytowani we wstępie do Norma vitae teologowie i prawnicy ${ }^{12}$.

Wedlug opinii cytowanego tam Rodericusa 13 oraz innych siedemnastowiecznych kanonistów, którzy w tej materii referowali jedynie aktualny stan prawny, eremici dzielili się na trzy grupy, tj. serbitów, anachoretów oraz cenobitów ${ }^{14}$. Już sam podzial eremitów na trzy kategorie oraz włączenie do nich cenobitów, których dawniej przeciwstawiano eremitom, świadczy zarówno o wielozmaczności pojęcia „e r e mita", jakk i o poszerzaniu jego zakresu znaczeniowego. $Z$ podziału zatem eremitów na trzy grupy wynika, iż termin ,e r e mi ci” (eremiti), podobnie zreszta jak i termin "monachus" (monachos) posiadał znaczenie o wiele szersze, niż to mu się pierwotnie zwykło przypisywać. Tak więc eremityzm obejmował: życie ściśle eremickie czyli pustelnicze, życie monastyczne oraz życie cenobickie, które początkowo przeciwstawiano życiu eremickiemu.

Mówiąc o ewolucji pojęcia ,e r e mita" należy zaznaczyć, że podobnie ma się rzecz z wyrażeniem "ordo", „ordines" załon, zakony, które z kolei, w zależności od rodzaju życia i podejmowanych prac, dzielą się na: kleryckie, laickie, żebrzące, nieżebrzące, kontemplacyjne, czynne, czynno-kontemplacyjne etc. ${ }^{15}$.

We wspomnianej już kilkakrotnie przedmowie do Norma vitae zaznaczono również, iż ci eremici, którzy przebywają w instytucie zatwierdzonym przez bisk ‘pa lub przez Stolicę Apostolską, pozbawieni są prawa posiadania jakiejkolwiek własności. $Z$ tej przeto racji zalicza się ich do osób kościelnych czyli zakonnych, gdyż podobnie jak zakonnicy, zrzekali się proprium ${ }^{16}$. A tego rodzaju eremici, jako że $w$ prawach $\mathrm{i}$ obowiązkach zostali zrównani $\mathrm{z}$ zakonami, dlatego uczestniczyli oni $w$ przywilejach przysługują-

12 Norma vitae „Praefatio informatoria”, 2.

${ }_{13}$ F. E. Rodericus, Quaestiones regulares et canonicae, Venetiis 1611, S. 151 .

${ }^{34}$ F. E. Rodericus, jw., s. 151; F. Cespedes, jw., s. 560; L. De Franchis, jw., s. 494; A. Reiffenstuel, Ius canonicum universum, t. III, Maceratae 1860, s. 4.

15 Kan. 488 (Kodeks z 1917 x.).

16 Norma vitae „Praefatio informatoria”, 2; F. E. Rodericus, jw., s. 151; F. Cespedes, jw., s. 560; L. De Franchis, jw., s. 494; A. Reiffenstuel, jw., s. 4. 
cych duchownym, tj. cieszyli się przywilejem forum, kanonu i immunitetu $\mathbf{1 7}$.

Norma vitae referując odnośnie eremitów prawo obowiązujące w XVII wieku, wspomina nadto o tak zwanych eremitach - pustelnikach, zaznaczając, że tego rodzaju eremici, chociaż nie muszą być aprobowani przez ordynariusza miejsca, to jednak powinni być przez niego uznani i we wszystkich sprawach całkowicie podlegać biskupowi, na którego terenie przebywają 18 .

Powyższy podział eremitów nie odnosi się do takiego rodzaju eremitów, ktọ́rzy wprawdzie przebywają w pustelniach, ale ani nie zachowują żadnej reguły (zatwierdzonego regulaminu) ani nie podlegają żadnej władzy. Tacy eremici nie mają nic wspólnego $z$ kanonicznym stanem realizacji rad ewangelicznych, a zaitem należą do grona osób świeckich 19.

Przedstawionych przed chwilą wywwodów nie dia się również zaaplikować do tych eremitów, którzy składają profesję zakonną, gdyż z racji egzempcji nie podlegają oni jurysdykcji miejscowego biskupa 20 .

Mówiąc o eremitach nasuwa się jeszcze inny problem. A mianowicie chodzi o takich eremitów, którzy zlożyli śluby zakonne w jakimś instytucie eremickim, chociażby zatwierdzonym przez biskupa. Czy mogli oni swobodnie opuścić instytut, a tym samym zmienić swój stan?

Odpowialdając na powyiższe py:tanie należy zaznaczyć, że prawo kościelne przewidywalo przypadki opuszczania instytutów przez eremitów - profesów. Musiało to nastąpić za dyspensą papieską i przy zachowaniu i spełnieniu ściśle określonych warunków. Warunki te były następujące: wyłączna prośba kompetentnego przelożonego, istnienie bardzo poważnych racji i wykluczenie jakiejkolwiek szkody dla osób trzecich 21.

A zatem eremici, o których wyżej mowa, nie składali ślubów uroczystych, gdyz od nich bowiem w tym czasie nigdy nie udzielano dyspensy 22. Wydaje się, że mogły to być jedynie przyrzeczenia zobowiązujące do wytrwania aż do śmierci w określonej instytucji 23 .

Należy nadto zaznaczyć, że eremici ci nie byli zobowiązani do zachowaniia stalości miejsca, mogli oni przeto przyijmować i zakla-

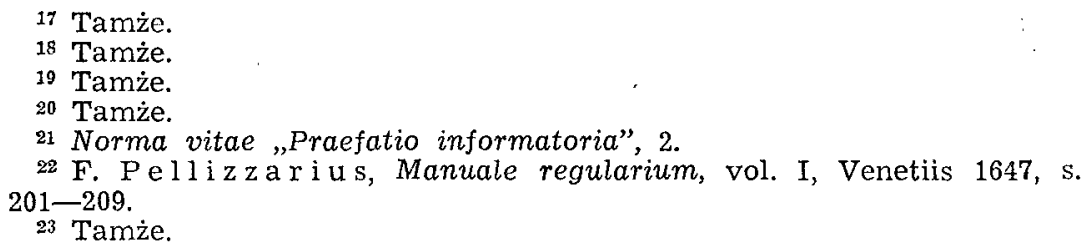


dać nowre placówkiki oraz utrzymywać tytulem paupertatis lub congregationis święcenia kapłańskie 24.

Pomimo to, że zakkon marianów, jalk to zaznaczono w przedmowie do Norma vitae, należał do jednej z grup eremitów, to jednak nie był on $w$ ścisłym tego słowa znaczeniu instytutem eremickim czyli oddanym życiu samotnemu - pustelniczemu. Członkowie zakonu marianów, oczywiście $z$ pewnymi ograniczeniami, mogli poświęcić się pracy duszpasterskiej lub nawet charytatywnej. Winni to jednak czynic bez szkody dla osób trzecich. Chodziło tu zasadniczo o to, by nie umniejszać innym zakonom źródeł dochodóxw materialnych, co następowało przez odciąganie wiernych od uczestnictwa $\mathrm{w}$ nabożeństwach w kościołach zakonnych wcześniej istniejących ${ }^{25}$.

Rozważając problem charakteru prawnego instytutu zapoczątkowanego przez o. Papczyńskiego rodzą się dodatkowe problemy. A mianowicie dlaczego w Norma vitae, oprócz różnych zagadnień dotyczących ex professo życia zakonnego, zamieszczono wstęp, w którym scharakteryzowano zarówno stan prawny instytutu marianów, jak i jego charakter?

Odpowiadając na powyższe pytanie należy przypomnieć fakt, iż w czasie układania przez o. Papczyńskiego Norma vitae nie było żadnych wyitycznych odnośnile do redakkcji konistytucji ${ }^{26}$. Taki stan trwal do początku dwudziestego wieku, tj. do chwili wydania przez Kongregację Biskupów i Zakonników w 1901 r. Norm 27. Stąd redakcja konstytucji zależała od inwencji redaktorów.

Zamieszczenie we wstępie do Norma vitae wyjaśnień o charakterze instytutu marianów wynikało $\mathrm{z}$ przyczyn niezależnych ani od o. Papczyńskiego ani od pierwszych marianów. Od samego mianowicie początku formowania zakonu marianów wyłaniały się liczne trudności oraz niejasności. Źródło zaś wszelkich nieporozumień tkwiło $w$ tym, iż zakon marianów był jednym $z$ pierwszych zakonów męskich zakładanych w Polsce i przez Polaka. Stąd zarówno sami biskupi, jak i inni, nie zawsze byli dobrze zaznajomieni $\mathrm{w}$ procedurze zakładania i zatwierdzania nowopowstających instytutów realizacji rad ewangelicznych.

Przechodząc do odpowiedzi na inne pytanie, tj. czy wstęp, w którym traktuje się o podziale eremitów i charakterze prawnym zakonu marianów, był pomysłem oryginalnym?

\footnotetext{
24 Norma vitae "Praefatio informatoria”, 2.

25 P. M. Passerinus, Commentaria in tertium librum Sexti Decretalium, Venetiis 1698 , s. $277-288$.

${ }_{26} \mathrm{R}$. L. Ravasi, De regulis et constitutionibus religiosorum, Romae 1958, s. 28.

27 Normae secundum quas $S$. Congr. Episcoporum et Regularium procedere solet in approbandis novis institutis votorum simplicium, T. $\mathrm{S}$ chaefer, De religiosis ad normam Codicis Iuris Canonici, ed. 4, Roma 1947, s. 1102-1135.
} 
Według wszelkiego prawdopodobieństwa przy redagowaniu przedmowy do Norma vitae wzorowano się na juz istniejących regułach i konstytucjach zakonnych. I tak św. Hieronim dzieli mnichów zwanych później także eremitami na trzy kategorie, tj. na cenobitów, anachoretów i remobitów ${ }^{28}$. Również i św. Benedykt w pierwszym rozdziale swojej reguły rozróżnia cztery kategorie mnichów, czyli: cenobitów, anachoretów, sarabaitów oraz tzw. mnichów wędrownych 29. Podobny podzial mnichów - eremitów zastosował św. Romuald, założyciel i autor konstytucji kamedułów ${ }^{30}$.

Również sławni delkretaliści siedemnastego wieku piszący traktaty $z$ prawa zakonnego, przynajmniej jeden punkt poświęcali podziałowi i omówieniu różnych kategorii eremitów ${ }^{31}$. Jak się wydaje czynili to $\mathrm{w}$ związku $z$ okolicznościami towarzyszącymi zatwierdzaniu instytutów zakonnych, ponieważ pierwotnie aprobowano tylko ordines czyli zakony o ślubach uroczystych 32 . Wprawdzie dawna dyscyplina $w$ tej materii nie została anulowana, ale w miarę wyłaniania się nowych potrzeb w Kościele, zaistniała konieczność erygowania takich form życia zakonnego, które by odpowiadaly aikitualnym zapotrzelbowaniom. Dlatego szukano nowych sposobów ich zakładania, a nawet często starano się obejść obowiązujące przepisy prawne.

\section{Cel ogólny i szczegółowy zakonu marianów}

Każdy instytut życia kionselkrowanego ma do spelinienia w Kościele i świecie specyficzne zadania, iktóre są określone w podistawowych aiktach prawnyoh, $t j$. w regulach $i$ konstytucjach.

Odnośnie do dziel, które powinny realizować wszystkie instytuty życia poświęconego Bogu, Sobór Watykański II stwierdza: „Stąd też wyrosły niby na drzewie, które się culdownie i bujnie rozkrzewiło na roli Pańskiej z danego przez Boga zalążka, rozmaite rodziny zakonne, które pomnażają to, co służy zarówno pożytkowi ich członków, jak i dobra całego Ciała Chrystusowego" 33.

Podobnie i o. Papczyński, przystępując do zakładania zakonu marianów oraz do redagowania konstytucji dla tegóz zakonu, $z$

28 Starożytne reguly zakonne, Warszawa 1980, s. 65-67.

29 Reguta świętego Benedykta, Tyniec 1979, s. 14-15.

30 L. Holstenius, Codex regularum, monasticarum et canonicarum, t. II, Additamentum XXI, Augustae Vindelicorum 1759, s. 201. 31 L. De Franchis, jw., s. 494 ; F. Cespedes, jw., s. 560 ; A. $R \in$ iffenstuel, jw. s. 4 .

${ }_{32}$ T. Sch a efer, jw., s. 1:13-114; A. Ga mbari, Institutorum saecularium et congregationum evolutio comparata, Commentarium pro religiosis et missionariis, 29 (1950) $226-234$.

33 Konstytucja dogmatyczna o Kościele „Lumen gentium”, n. 43. 
konieczności musial nalkreślić swemu insitytultowi cel, który powinien on realizować w przyszłości.

Mówiąc o celu należy zaznaczyć, że jest on podwójny, tj. ogólny i sżczególowy. Cel ogólny, jak na to wskazuje jego nazwa, jest wspólny dla wszystkich instytutów życia konsekrowanego. Tym zaś, co wyróżnia jeden instytut od drugiegio, jest cel szczegółowy, który stanowi o specyfice poszczególnych gnup instytutów zalkonnych.

Według Norma vitae wszyscy członkowie zakonu marianów mają przede wszystkim obowiązek troszczenia się o wzrost chwały Bożej oraz usilne dążenie do osiągnięcia osobistej świętości ${ }^{34}$.

$\mathrm{Za}$ główny motyw, który miał członków zakonu marianów pobudzać do własnego uświęcenia, o. Papczyński uważa słowa Chrystusa: „Cóż bowiem za korzyść odniesie człowiek, choćby cały świat zyskał, a na swej duszy szkodę poniósł? Albo co da człowiek w zamian za swoją duszę" 35 ?

Według zaleceń Norma vitae celem szczegółowym zakonu marianów jest: troska o szerzenie kultu Niepokalanego Poczęcia Najświętszej Maryi Panny i modlitwa za dusze w czyścu cierpiące. Szczególnie zaś członkowie zakonu marianów powinni się modlić za dusze poległych w różnych bitwach żołnierzy oraz za zmarłych w czasie epidemii ${ }^{36}$.

Innym charakterystyicznym i ważnym zadaniem, nalożonym marianom przez Norma vitae, była pomoc proboszczom w pracy duszpasterskiej. Mówiąc zaś o tym zaleceniu o. Papczyński nie poleca stosować się do niego $z$ bezwzględną koniecznością. A można się przekonać o tym z zamieszczonego $w$ tej materii w Norma vitae tekstu, który brzmi: „Wprawdzie nie będzie zabronione, aby ci, którzy zostali obdarneni odpowiednimi uzdolnieniami, magli służyć proboszczom pomoca w pracy duszpasterskiej" 37. O. Papczyński pomoc proboszczom w pracy duszpastersikiej uzależnił od naturalnych przymiotów marianów, od wystarczającego przygotowania i gruntownej formacjii zakonnej.

Gdyby zaś autor Norma vitae stawiał na równi $z$ innymi zadaniami pomoc proboszczom w pracy duszpasterskiej czyli uważał ją za cel szczegółowy par excellence, wówczas powinien był to wyrazic w jasnych słowach i użyć sformułowania albo imperatywnego, albo jemu podobnego, a nie takiego jakie zastosował w Norma vitae: "Quamquam non prohibebuntur, qui fuerint eiusmodi talentis dotati, parochos in laboribus ecclesiasticis humiliter adiuvare" 38 .

\footnotetext{
34 Norma vitae, I, 2.

95 Mt 16, 26.

36 Norma vitae, I, 2.

37 Tamże, $\mathrm{I}, 3$.

38 Tamże.
} 
Należy nadto podkreślić, iż zgodnie z prawem kościelnym autor Norma vitae uzależnił pomoc proboszczom od uzyskania uprzednich uprawnień tak od ordynariusza miejsca, jak i od właściwego przełożonego zakonnego.

Celem uniknięcia ewentualnego zarzutu jakoby praca duszpasterska, czyli pomoc proboszczom stała w sprzeczności z charakterem prawnym marianów, o. Papczyński wyjaśnił w Norma vitae, że chociaż zakon marianów zostal erygowany, in statu e remiti c o", to jednak mimo wszystko, nie zalicza się go do instytutów kontemplacyjnych $w$ ścisłym znaczeniu tego słowa ${ }^{39}$.

\section{Srodki do osiągnięcia celów}

Każdy z zakonodawców zakładając instytut realizacji rad ewangelicznych, wyznacza mu nie tylko cel ogólny, ale przepisuje również środki, przy pomocy których cele te powinny być realizowane.

Mówiąc o celu szczegółowym, czy specyficznym zadaniu danego instytutu, należy zauważyć, iż od dokładnej jego realizacji oraz od stosowania środków polecanych przez założycieli, zalleży, jak uczy doświadczenie, rozwój i prężność instytutów zakonnych ${ }^{40}$.

Dlatego i zakonodawca marianów idąc za wielowiekowym doświadczeniem Kościoła oraz wzorując się na różnych regułach i konstytucjach zakonnych podał marianom środlki służące do realizacji celów. Ponieważ zaś o. Papczyński nie poświęca osobnego rozdziału Norma vitae kwestii dotycżącej tych środków, przeto $\mathrm{z}$ konieczności należy szukać o nich wzmianki w całym dziele Norma vitae.

Pomimo jednak takiego ustawienia problemu, nie można o. Papczyńskiemu zarzucić braku logiczności i niekonsekwencji, gdyż do końca dziewiętnastego wieku ani praktyka, ani Stolica Apostolska nie wytworzyła żadnych schematów dotyczących układania konstytucji zakonnych 41 .

Wydaje się, że omawianiu środków koniecznych do realizacji

39 Tamże.

40 Normae secundum quas $S$. Congr. Episcoporum et Regularium procedere solet in approbandis novis institutis votorum simplicium, jw., n. 42-47; P a w el VI, Przemówienie do uczestników kapitut generalnych, $23 \mathrm{~V}$ 1964, Charyzmat życia zakonnego. Przemówienia i dokumenty. Wybór i opracowanie A. Ż u chow ski, T. Sulow ska, Pallottinum 1974, s. 85; Tenże, Przemówienie do uczestników kapituly generalnej zgromadzenia Slowa Bożego, 22 I 1968. s. 154-155; Dekret o przystosowanej odnowie życia zakonnego „Perfectae caritatis", Sobór Watykański II, Konstytucje, dekrety, deklaracje, Poznań 1968, n. 2, s. 265-266; P a o 10 VI, Es. Ap. Evangelica testificatio. Il rinnovamento della vita religiosa secondo il Concilio, $\mathrm{n}$. 11, La vita religiosa. Documenti a: cura di A. $R$ a va z zi, Milano 1972, s. 555.

41 R. L. Ravasi, jw., s. 28. 
celu ogólnego o. Papiczyńlski poświęcił cały rozdzial drogi zatyitulowany De charitate. Za przyjęciem takiego twierdzenia zdają się przemawiać następujące argumenty:

1) Zamieszczenie tego rozdziału po omówieniu charakteru instytutu, celu ogólnego i szczegółowego, przyjęcia kandydatów do instytutu, ich formacji etc.

2) Zarówno konstrukcja rozdzialu, jalk i treść w nim zawarta świadczą o tym, że chodzi o środki niezbędne do zrealizowania celu ogólnego.

3) Rozdział ten byłby niezrozumiały i nie miałby sensu, gdyby nie zawierał wskazań do osiągnięcia celu ogólnego.

4) Omawiane są w nim wszystkie aspekty, różne przejawy i hierarchia jaką należy zachować przy praktykowaniu miłości, tj. podstawowej cnoty chrześcijańskiej.

Można by przytaczać i inne dowody świadczące o tym, że w rozdziale De charitate autorowi Norma vitae chodziło o środki, jalkie odinośnie do osilągnięcia celu ogólnıgo powwinni podejmować członikowie zalkonu marianów. By jednak zagadnienie wyczempać do końca wydiaje się, że będzie rzeczą stosomną postawienie pad adresem autora Norma vitae dodatkowego pytania, czy mianowicie rozdział drugi Norma vitae zatytułowany De charitae jest oryginalnym pomysłem autora oraz czy jest wzorowany na jakichś bardziej lub mniej znanych regułach lub konstytucjach zakonnych?

Odpowiadając na powyższe pytania należy zaznaczyć, że w niektórych regułach zakonnych zamieszczano odrębne rozdziały traktujące ex professo o miłości w życiu zakonnym. I tak w regule przeznaczonej dla klasztoru Ferriolacensis po rozdziale o posłuszeństwie następuje rozdział o miłości 42. Równiez rozdział pierwszy reguły świętego Augustyna zawiera wskazania dotyczące miłości Boga i bliźniego 43. Podobnie i konstytucje kamedułów miłość uważają za instrument dobrych i zasługujących uczynków na życie wieczne i omawiają tę kwestię w rozdziale czwartym zatytulowanym: Quae sint instrumenta bonorum operum 44.

$\mathrm{Na}$ podstawie tego co już powiedzianю ryżej, mюżna by wyciagnąć wniosek, że o. Papczyńsiki wzorowal się na wcześniejiszych regulach i konstytucjach zakonnych, jeśli nie co do treści, to przyunajmniej co do ogólnej kxonstrukcji.

Po zasygnalizowaniu niektórych kwestii, i to raczej natury drugorzędnej, mających związek $\mathrm{z}$ rozdziałem $\mathrm{De}$ charitate, obecnie

${ }^{42}$ Regula monasterii Ferriolacensis, L. Holstenius, Codex regularum, monasticarum et canonicarum, Augustae Vindelicorum, t. I, 1759 , s. $156-157$.

${ }^{43}$ Reguła świętego Augustyna, Starożytne reguły zakonne, jw., s. $156-157$.

${ }^{44}$ Constitutiones Congregationis Cameldulensis, Codex regularum, monasticarum et canonicarum, t. II, Additamentum XXI, jw., 207-208. 
poddane będą analizie wskazania o. Papczyńskiego odnoszące się do realizacji celu ogólnego.

Przede wszystkim zaskuguje na uwagę fakt, iż już od pierwszych słów rozpoczynających rozdział o miłości, o. Papczyński parafrazuje tekst św. Pawła Apostoła z pierwszego listu do Koryntian z rozdz. 13, i zgodnie $\mathrm{z}$ nauka Apostoła tego, kto nie chce realizować miłości, porównuje do miedzi brzęczącej i cymbała brzmiącego ${ }^{45}$. O. Papczyński przypomina również nauczanie Kościoła zaznaczając, iź zarówno osiągnięcie zbawienia, jak i zdobycie zasług za spełnienie dobrych uczynków, uzależnione jest od miłości $46 . Z$ tej racji, każdy $z$ marianów powinien ponad wszystko przenosić miłość, uważać ją za najcenniejszą perłę oraz za skarb ukryty w roli 47 .

W dalszej części rozważań o miłości o. Papczyński, w oparciu o naukę Kościoła katolickiego stwierdza, że wprawdzie miłość jest jedną $z$ trzech cnót boskich, ale do jej podtrzymania i zachowania przyczynia się ustawiczna modlitwa, umartwienie czyli czuwanie nad swoimi zmysłami oraz praca nad udoskonaleniem samego siebie 48 .

$\mathrm{W}$ celu podkreślenia i uzasadnienia znaczenia miłości w życiu chrześcijańskim, a szczególnie $\mathrm{w}$ życiu zakonnym, o. Papczyński zaleca członkom swego zakonu, by przy podejmowaniu jakichkolwiek dziel, zawsze kierowali się miłością ${ }^{49}$. Dlatego wszyscy czlonkowie zakonu marianów $\mathrm{z}$ milości ku Bogu powinni zachowywać przykazania Boże, rady ewangeliczne, zarządzenia Kościoła rzymsko-katolickiego, wszystkie instytucje zatwierdzone przez władzę kościelną, ryty, zwyczaje, regułę czyli Norma vitae oraz inne decyzje kościelne 50.

Ponieważ zaś miłość jest motywem wszelkiej działalności oraz źródłem dobrych uczynków, dlatego podkreśla o. Papczyński, by ze względu na nią podejmować się dzieł, rozwijać w sobie cnoty, unikać zła, oraz nlienawidzzieć waidy i grzechy ${ }^{51}$.

Nadto, według doktryny o. Papczyńskikiego, marianie kierując się tylko miłością, powinni chętnie i dobrowolnie ćwiczyć się $\mathrm{W}$ różnych umartwieniach, w znoszeniu wszelkich doświadczeń, ucisków, nieprawości oraz innych niewygód dnia codziennego 52 . Także wszelkie praktyki religijne, powierzone przez władzę zakonną obowiązki, codzienne zajęcia, cierpienia, zmiany placówek, choćby

\footnotetext{
451 Kor. 13,1 ; Norma vitae, II, 1.

${ }^{40}$ Norma vitae, II, 1.

47 Tamże.

48 Tamże.

49 Tamże.

so Tamże, II, 2.

51 Tamże, II, 3.

52 Tamże.
} 
były bolesne, a również inne nawet najmniejsze czynności, marianie mają obowiązek wypełniać z czystą intencją, pobożnością, bez oglądania się na osiągnięcie zysków doczesnych, ale zawsze z myślą o Bogu, o ofiarowaniu się Chrystusowi, Matce Bożej Niepokalanie Poczętej, świętym oraz o powiększeniu zasług Kościoła powszechnege 53 .

Skoro podstawową regulą oraz najpewniejszą drogą do realizacji celu ogólnego jest cnota miłości, to pierwszoplanową regułę dla marianów powinien stanowić nakaz Chrystusa: „Będziesz miłowal Pana Boga twego, $z$ całego serca, $z$ całej duszy swojej, ze wszystkich sił swoich" 54 .

Przechodząc z kolei do omawiania milości braterskiej, autor Norma vitae wskazuje na konkretne oraz bezwzględnie konieczne środki do jej realizowania. Mówiąc o wzajemnej miłości braterskiej o. Papczyński zaznacza, że miarą wielkości zakonnika jest praktykowanie i wyróżnianie się $\mathrm{w}$ miłości bliźniego. Wszelkie natomiast zaniedbanie $\mathrm{w}$ dziedzinie miłości jest równoznaczne $\mathrm{z}$ oddalaniem się od życia 55. O. Papczyński przypomina wszystkim marianom, iż na podstawie powołania zakonnego, zostali zobligowani do czynienia postępów w praktykowaniu miłości, strzeżenia jej oraz uważania ją za pođstawową zasadę świętości i nienaruszalności dla całego zakonu $\mathbf{5 6}$.

Autor Norma vitae konkluduje, że nieodzownym środkiem dla zachowania wzajemnej miłości jest unikanie i wystrzeganie się wad przeciwnych tej cnocie, jak: zazdrości, nienawiści, zawziętości, nieżyczliwości, zniesławienia, antypatii, wzajemnego oskarżania się, donosicielstwa, szemrania, obmowy, stronniczości, pogardy dla innych, zamętu, kłótni, sporów etc.

Według wskazań zamieszczonych w Norma vitae na tyle każdy z marianów ma prawo do miłości, na ile ją wyświadeza innym, czyli, jak dokładniej to precyzuje o. Papczyński, wszyscy marianie tak, jak zabiegają o pozyskanie milości i spokoju dla siebie, takk samo niech się starają o nia dla inych oraz dla domu zakonnego, w którym przebywają 57. Ponadito o. Papczyński usilnie zaleca, by marianie przeciwdzialali jalkiejlkolwiek niepraw.ości $i$ to zarówno $\mathrm{w}$ odniesieniu do calego zakonu, jak i w stosunku do poszczególnych jego członków 58 .

Co się tyczy wzajemnej miłości Norma vitae przypomina inną powszechnie znaną zasadę ewangeliczną, według której miłość obejmuje również przeciwników i prześladowców oraz osoby spoza za-

\footnotetext{
53 Tamże.

54 Pwt 6, 5; Norma vitae, II, 3.

55 Norma vitae, II, 4.

56 Tamże.

57 Tamże.

58 Tamże.
} 
konu 59. Za wzór miłości autor Norma vitae stawia życie pierwszych chrześcijan $\mathbf{6 0}$.

Kończąc rozważania o wskazaniach o. Papczyńskiego odnoszących się do zachowania ładu, porządku oraz miłości wzajemnej należy stwierdzić, że środki zalecane przez Norma vitae nie są oryginalnym pomysłem o. Papczyńskiego, gdyż były powszechnie znane, stosowane oraz zalecane zarówno przez różne podręczniki ascetyczne i prawne, jak i przez reguły, a także konstytucje zakonne 61 .

Jest rzeczą godną do odnotowania, iż o ile w Norma vitae o. Papczyński stosunkowo dużo uwagi poświęcił omawianiu niezbędnych środków do realizowania celu ogólnego, o tyle natomiast mniej, a nawet bardzo mało zajął się środkami, przy zastosowaniu których mieli marianie wypełniać swoje specyficzne posłannnictwo w Kościele.

Środki służące do realizacji celu szczegółowego, jakie według wskazań Norma vitae mieli stosować marianie, sprowadzały się do codziennego odmawiania Małego Oficjum ku czci Matki Bożej, odmawiania oficjum za dusze $\mathrm{w}$ czyścu cierpiące, odmawiania calego różańca oraz odprawiania Mszy św. za dusze w czyścu cierpiące 62. Również kaplani powinni często odprawiać Msze św. za dusze w czyścu cierpiące ${ }^{63}$.

Prawodawca instytutu marianów w rozdziale De congregationibus habendis zaleca, by na odgłos dzwonka wszyscy zgromadzili się wspólnie w celu wspomożenia duszy jakiegoś współbrata umierającego. Duszę umierającego mają polecać dobroci i miłosierdziu Bożemu, aktami strzelistymi, pokornymi lzami, wspierając ją po bratersku ze wszystkich sil, aby ktoś w chwili śmierci nie znajdowal się $\mathrm{w}$ niebezpieczeństwie utraty zbawienia ${ }^{64}$. Nadto przełożony dołoży wszelkiej troski, aby choremu dostarczyć z największą miłością nie tylko środlków dila odzyskania zdrowia, lecz szczególnie zatroszczyć się o życie wieczne. Srodkami tymi są: spowiedź, żal za grzechy, wyznanie wiary, protest przeciwko pokusom szatańskim, oddanie duszy swojej Bogu i w ręce spowiednika, pobożne przyjęcie Eucharystii, sakramentu chorych, wzywa-

59 Tamże, II, 5.

$60 \mathrm{Dz} .4,32$.

61 Regula św. Pachomiusza, Starożytne reguły zakonne, jw., s. 57- 59; Regula św. Augustyna, 1, 2, s. 93; VI, 3, s. 99; Reguła św. Cezarego $z$ Arles dla mnichów, s. 117-118; Reguła Pawła i Stefana, s. 145; Reguła Mistrza, s. 161; Reguła św. Benedykta, s. 188-190; Reguła św. Kolumbana, s. 242; Reguta św. Izydora z Selvilli, s. 302-303.

62 Norma vitae, IV, 5; VI, 4; VIII, 2, 3.

${ }_{63}$ Tamże, VIIr, 2.

64 Tamże, IX, 5. 
nie pomocy duchów niebieskich, całkowita nadzieja i zaufanie $\mathrm{w}$ zasługi Jezusa Chrystusa 65.

Modlitwy zalecane przez Kościól w intencji konających należało odmawiać pobożnie, polecać duszę Bogu, zwłoki przyzwoicie okryć i pochować je w ciągu trzech dni oraz jak najprędzej zawiadomić inne domy, by swoimi modlitwami i umartwieniami polecali zmarłego Bogu 66 .

\section{Rady ewangeliczne}

Rady ewangeliczne stanorwią istotny element dla wszelkich form życia poświęconego Bogu. Dlatego z konieczności wszystkie reguły i konstytucje poświęcają temu zagadnieniu dużo uwagi. Wprawdzie rady ewangeliczne wywodzą się z jednego źródła, ale, jak czytamy w uchwałach Soboru Watykańskiego II, sposób ich praktykowania jest różny i zależy od charakteru poszczególnych instytutów zakonnych. Oto co na ten temat pisze Sobór Watykański II: „Rady ewangeliczne dotyczące poświęconej Bogu czystości, ubóstwa i posłuszeństwa, jako ugruntowane $\mathrm{w}$ słowach i przykładach Pana, a zalecane przez Apostołów, Ojców i doktorów Kościoła oraz pasterzy, są darem Bożym, który Kościół otrzymał od swego Pana i z łaski Jego ustawicznie zachowuje. Sama zaś władza Kościoła pod przewodnictwem Ducha Świętego zatroszczyła się o to, aby je tłumaczyć, praktykowaniem ich kierować, a nadto ustanawiać stałe, trwałe formy życia na radach tych oparte. Stąd też wyrosły niby na drzewie, które się cudownie i bujnie rozkrzewilo na roli Pańskiej z danego przez Boga zalążka, rozmaite formy życia samotnego lub wspólnego, rozmaite rodziny zakonne..." 67.

\section{Postuszeñstwo}

Przystępując do analizowania rady ewangelicznej posłuszeństwa należy zasygnalizować, iż o. Papczyński porusza istotne problemy mające związek ze ślubem posłuszeństwa. A zatem autor omawia takie problemy jak: hierarchię posłuszeństwa 68 ; pochodzenie władzy ${ }^{69}$; motywy posłuszeństwa ${ }^{70}$; sposób rozstrzygania sporów ${ }^{71}$; przymioty posłuszeństwa ${ }^{72}$ etc.

Autor Norma vitae idąc za nauką Kościoła katolickiego stwier$\mathrm{dza}$, iż w praktykowaniu rady ewangelicznej posłuszeństwa wi-

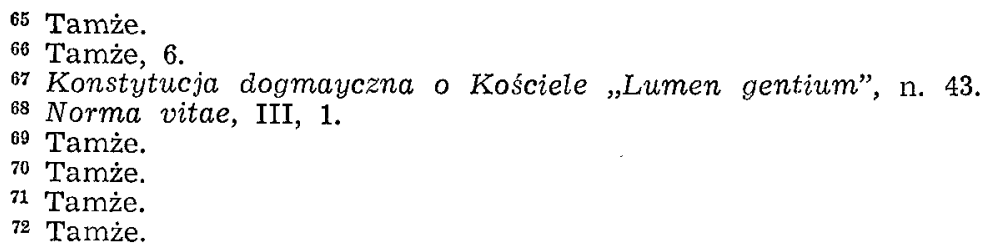


nien być zachowany porządek, który uzależniony jest od godności osoby wydającej polecenie. Według zaleceń Norma vitae członkowie zakonu marianów na pierwszym planie mają okazywać posłuszeństwo Bogu ${ }^{73}$ oraz papieżowi 74, gdyż jako następca św. Piotra sprawuje on najwyższą władzę nad wszystkimi wiernymi, a więc i zakonami 75. O. Paczyński poleca również, by marianie byli ulegli biskupom, przełożonym zakonnym, ich zastępcom oraz dzwonkom wzywającym na wspólne ćwiczenia zakonne ${ }^{76}$.

Należy zaznaczyć, że zalecana przez o. Papczyńskiego hierarchia. przy wypełnianiu posłuszeństwa była w owym czasie ogólnie znana. We wszystkich bowiem dziełach traktujących o życiu zakonnym 77, a zwłaszcza o jego obowiązkach, stawiano pytanie: „Quo ordine teneatur religiosus obedire praelatis regularibus vi voti obedientiae" i dawano wyczerpujące odpowiedzi 78.

W celu uniknięcia i zaradzenia ewentualnym nieporozumieniom, mogącym wyniknąc w wypełnianiu rozkazów i poleceń, o. Papczyński przytacza powszechnie znaną zasadę, w myśl której władza niższa podlega wyższej, dlatego w niczym nie może się jej spmzeciwić, lub w jakkikolwiek sposób osłabić jej poleceń 79. Prawodawca marianów przypomniał również inną regułę, według której rozkaz późniejszy anuluje wcześniejszy, o ile jest mu przeciwny ${ }^{80}$.

Przechodząc do omawiania motywów posłuszeństwa o. Papczyński, podobnie jak to czynią inne reguły $\mathrm{i}$ konstytucje zakonne, zaznacza, że jest nim przyklad Jezusa Chrystusa ${ }^{81}$. W celu udowodnienia powyższego twierdzenia Norma vitae przytacza słowa Pisma świętego: „Uniżyl samego siebie stawszy się posłusznym aż do śmierci - i to śmierci krzyżowej" 28 . Z tej racji, kontynuuje autor Norma vitae, ci, którzy wzbraniają się przed naśladowaniem Chrystusa $w$ posłuszeństwie tym samym nie cheą $z$ Nim królować ${ }^{83}$. A wszelkie akty posłuszeństwa marianie mieli spełniać chętnie, cierpliwie, pokornie oraz wytrwale ${ }^{84}$.

Odnośnie motywów posłuszeństwa o. Papczyński cytuje także

73 Tamże.

74 Tamże.

75 Norma vitae, III, 1; F. Pellizzarius, jw., s. 435 ; J. B. L ezana, Summa quaestionum regularium, vol. II, p. II, Romae 1640, s. 25.

${ }^{76}$ Norma vitae, IIr, 1; Por. F. Pellizzarius, jw., s. 437-438.

7 F. Pellizzarius, jw., s. $422-423$; J. B. Lezana, jw., s. 25.

78 Tamże.

79 Norma vitae, III, 1.

so Norma vitae, III, 1; VI ${ }^{\circ}$ I, $2,1$.

81 Norma vitae, III, 1 .

82 Flp 2, 8.

83 Norma vitae, III, 1; $\mathrm{Rz} 13,1-2$.

84 Norma vitae, III, 1. 
słova św. Piotra Apostoła, które brzmią: „Bądźcie poddani każdej ludzkiej zwierzchności ze względu na Pana. Czy to królowi jako mającemu władze, czy to namiestnikom przez niego powołanym celem karania złoczyńców, udzielania zaś pochwały tym, którzy dobrze czynią" 85.

Należy zaznaczyć, że doktryna o. Papczyńskiego dotycząca uległości władzy, jej pochodzenia oraz motywów posłuszeństwa, zawarta w Norma vitae, jak można się przekonać z następującego zestawienia tekstów, opiera się na podstawach biblijnych:

„Neque vereamini subdi hominibus, cum Apostolus velit nos omni creaturae subditos esse, multo magis omni potestati" 86 .

,Nom est enim... potestas, nisi a Deo, hinc qui resistit potestati, Divinae ordinationi resistit, quod maximae situltitiae genus est" 88.

,Motivum et exemplum obedientiae sumatis ab ipso Redempitore Nostro, qui ,humiliavit semetipsum factus obediens usque ad mortem, mortem autem crucis" 90 .

"Qua in re, qui eum detrectaret imitari, hunc appareret nolle cum Christo regnare, si nolle $\frac{t}{t}$ obsequi delbitae authoritati pro Christo" 92.
„Subiecti estote omni humanae creaturae propter Deum: sive regi quasi praecellenti: sive ducibus tamquam ab eo missis ad vindictam malefactorum laudem vero bonorum" 87 . „Omnis anima potestatibus sublimioribus ssubdita sit: non est enim potestas nisi a Deo, quae artem sunt a Deo, ordinatae sunt. Itaque qui resistit potestati, Dei ordinationi resistit: qui autem resistunt, ipsi sibi damnationem adquirunt"89. „Humiliavit semetipsum, factus oboediens usque ad mortem, mortem autem, crucis" 91.

,$\ldots$ qui resistit potestati, Dei ordinationi resistit: qui autem resistunt ipsi sibi damnationem adquirunt" 93.

O. Papczyński omawia problem posłuszeństwa nie tylko na płaszczyźnie teoretycznej, ale stara się również rozwiązywać różne kwwestie praktyczne. I tak odnośnie do relacji biskup - przelożo-

\footnotetext{
851 P 2, 13-15.

80 Norma vitae, III, 1.

871 P 2, 13-15.

so Norma vitae, III, 1.

$89 \mathrm{Rz} 13,1-2$.

90 Norma vitae, III, 1.

${ }^{9}$ Flp 2, 8.

92 Norma vitae, III, 1 .

${ }^{93}$ Flp 2, 8.

9 - Prawo Kanoniczne
} 
ny zakonny, autor Norma vitae pisze, iż wprawdzie wszyscy marianie winni okazywać biskupom należny szacunek, to jednak celem zapobieżenia mogącym wyniknąc perturbacjom, sami tylko przełożeni będą się $\mathrm{z}$ nimi dkontaktowali oraz omawiali wszelkie kwestie ${ }^{94}$. Najpra'wdiopodolbniej o. Papczyńskiemu chodzilo tu głównie o przypomnienie marianom zasady, iz w sprawach dotyczących dysicypliny zakonnej, zakonnicy podlegają władzy przelożonych 95 .

Inną, bardzo ważną oraz praktyczną, a zarazem znaną normą było przypomnienie marianom, iż dia uniknięcia zgorszenia i bumtów nikt $z$ podłwładnyrch nie ma prawa pozywania przełożonych przed saidy świeckie luib konsystorskie ${ }^{96}$. Gdyby jednak zdarzyły się jakieś spory lub nieporozumienia, wówczas powinno się je rozstrzygnąc wewnątrz zalkonu i bez odnoszenia się do czynnilków zewnętrznych ${ }^{97}$.

$\mathrm{Z}$ doświadczenia wiadomo, że wszelkie normy regulujące calość życia sciśle określonej grupy społecznej, oprócz przepisów zachęcających, porządkowych etc., muszą zawierać sankcje karne wymierzone przeciwko osobom wyłamu jącym się spod idyscypliny. Odnośnie do stosowania środków karnych o. Papczyński pisze w Norma vitae, iż w przypadku zaistnienia potrzeby należy majpierw dać obwinionemu możliwość słusznej obrony oraz zadośćuczynienia za popelnione winy. Dopiero zaś $w$ razie uzasadnionej kzonieczności można było przystąpić do zastosowania prawnych środków zaradczych, a gdyby $i$ one nie odniosły pożądanych skutków, wówċas wolno było wezwać na pomoc wladzę świecką, czyli posłużyć się tzw. „brachium saeculare" 98.

O. Papczyński nie tyllko poleca stosowanie względem opornych różnych srodków zaradczych, ale uzasadnia konieczność ich aplikowania. Według naulki zamieszczonej w Norma vitae przez ślub posłuszeństwa zakonnik nieodwołalnie ofiarowuje się Bogu, z tego zatem tytułu na wszystkich osobach zalkonnych ciąży obowiązek cierpliwego znoszenia wszellkich niewygód, nałożonych przez przełożonych pokut i umartwień oraz wprowadzanie pokoju, łagodności, a nie zamętu i mienawiści 99. Naidto o. Papczyński zaleca, by nikt $\mathrm{z}$ zakonników mie ośmielal się skarżyć na przełożonych, ale ich milowal i czcił 100.

94 Norma vitae, III, 1.

${ }_{95}$ F. Pellizzarius, jw., s. 437.

96 Norma vitae, III, 1; D. XCVI, 5, 11, 12; C. XI, q. 1, c. 1-3, 5-8, $10,11 \mathrm{dp}, 12-17,38-40,42-46,47 \mathrm{dp}$; X. II, $1,2,9,12,18 ; \mathrm{X}$. II, 8 , 1,$17 ; \mathrm{X} . \mathrm{V}, 31,15 ; \mathrm{VI}^{\circ}$. II, 2, 2; VI․ III, 2,$1 ; \mathrm{VI}^{\circ} . \mathrm{V}, 11,12$.

97 Norma vitae, III, 1.

98 Tamże.

99 Tamże.

100 Tamże. 
Pomimo jednak całkowitej uległości wobec przełożonych, Norma vitae przerwiduje wypadek albo niemożności wypelnienia poleceń lub obowiązków, albo uzasadnioną trudność icoh wykonania. W takich przypadkach podwładni mieli obowiązek powiadomić o tym przełożonych 101.

\section{Ubóstwo}

O. Papczyński przypomina, że istota ślubu ubóstwa polega na dobrowolnym wyzbyciu się wszelkiej iwłasności. Dlatego, bez zgody właściwy.ch przełożonych, nikomu z marianów nie wolno posiadać jakiejkolwiek rzeczy ${ }^{102}$.

Ponadto o. Papczyński przytacza w Norma vitae inna powszechnie obowiązującą i znaną zasadę, w myśl której wszelkie dochody pochodzące czy to $z$ jałmuziny 'czy $z$ jakiegokolwiek innego źródła winny być przeznaczone i przekazane ma wspólny użytek. O. Papczyński wzorując się na prawie powszechnym zaznaczył tak$\dot{z ̇ e}$ iż przy administrowaniu dobrami kościelnymi oraz ich rozdzielaniu zawsze należy zachować prawo kościelne. Wszyscy natomiast sprzeniewierzający się wytycznym Kościoła zaciągają kary przewidziane $w$ prawie dekretałów 103. Ponieważ zaś ślub rubóstwa pociągal za sobą wyrzeczenie się wszelkiego prawa wlasności, przeto bez uprzedniego pozwolenia przelożonych, i to pod sankcją utraty głosu czynnego i biernego zabroniono zatrzymywania lub przechowywania jakiejkolwiek rzeczy materialnej. Jedynie whaściwy przelożony, ale tylko względem zakonników podeszlego wieku i chorych oraz z wylkluczeniem wszelkiego zgonszenia, posiadal władzę uchylenia mocy obowiązującej od powyższej zasady, a zatem móg1 im pozwolić na przetrzymywanie u siebie pokarmów.

Ponadto na mocy licznych zarządzeń prawa powszechnego wydanych w materii ubóstwa, na wszystkich zakonnilkach ciążył obowiązek korzystania zarówno ze wspólnego s'tołu, jak i wspólnej kasy. $Z$ tej zatem racji milkt $z$ marianów bez wiedzy i zgody przełożonych nie mógł ani od nilkogo nic przyjmować ani przekazywać 104 .

O. Papczyńsiki, zgodnie zresztą z rozporządzeniem soboru Try-

101 Tamże, III, 2.

102 Norma vitae, III, 2; Reguła św. Augustyna, jw.; s. 93, 101; Reguła św. Cezarego $z$ Arles dla mnichów, jw., s. 116; Tenże, Reguła dla dziewic, jw., s. 125, 134; Reguta św. Kolumbana, jw., s. 244 ; C. XII, q. 1, c. 1, 5-11; X. III, 31, 5; X. III, 35, 2, 6; Concilium Tridentinum, sess. 25 , decretum de regularibus et monialibus, c. 2, Conciliorum oecumenicorum decreta, ed. III, Bologna 1973, s. 776-777; B. L e z a n a, jw., s. 30 .

103 Norma vitae, III, 3.

104 Tamże: 
denckiego 105, poleca, by, o ile nie zachodzi jakaś prawna przeszkoda, nowicjusze przed złożeniem pierwszej profesji, zrzekli sie na rzecz dowolnie obranej przez siebie osoby własnego majątku ${ }^{106 .}$

O. Papczyński, podobnie jak i inni zakonodawcy, przewidując, iż ślub ubóstwa powoduje ograniczenia w zakresie używania dóbr materialnych, a jednocześnie pragnąc uczynić mniej uciążliwymi różnego rodzaju ibraki, kieruje prośbe pod adresem przelożonych, by oni troszczyli się o zapewnienie każdemu ze swoich podwladnych rzeczy koniecznych, ale nie zbytecznych ${ }^{107}$. W Norma vitae zaznaczono również, że podwładni, na tylle staną się uczniami i maśladowcami ubogiego Chrystusa, na ile cierpliwie będą znosić utrapienia i na ile rozmiłują się w ubóstwie Chrysitusa 108.

W konkluzji należy zaznaczyć, że odnośnie do ewangelicznej rady ubóstwa, o. Papczyński nie wniósł nic nowego do Norma vitae, jak na to wskazują poniżej zestawione teksty źródłowe, lecz wszystko przejął z powszechnego prawa kościelnego.

„Paupertatis vestrae in hoc essentia consistit, ut nullus quidquam absque superiorum conisensu privatim habere, nec aliquod proprinum appellare audeat" 109. ,...illi enim uictu et uestitu contenti nullam inter se proprietatem habentes, debent habere omnia communia" 110.

"Quia tua fraternitas monasterii regulis erudita seorsum non debet fieri a clericis suis in ecclesia Anglorum, que auctore Deo muper ad fidem perducta est, hanc debet instituere conuersationem, que in inicio fuilt Patribus nostris, in quibus nullus eorum ex his, que possidelbat, proprium habebat, sed erant illis omnia communia" 111.

„§ 1. Quicumque uestrum communem uitam susceptam habet,

\footnotetext{
105 Concilium Tridentinum, sess. 25, decretum de regularibus et monialibus, c. 16, Conciliorum oecumenicorum decreta, jw., s. 781; Norma vitae, III, 2.

106 Tamże.

107 Norma vitae, III, 3, 2.

108 Tamże.

109 Tamże, III, 2.

110 C. XII, q. 1, c. 7.

111 C. XII, q. 1, c. 8.
} 
et uouit se nichil proprium habere..." 112 .

„§ 1. Nulli in societate nostra licet aliquid habere proprium; sed forte aliqui thaibent, nulli licet, sed qui habuerint faciunt quod non licet... \& 3. Qui habuerit proprium, uel habere uoluerit, et de proprio uivere, et contra precepta ista facere, parum est ut dicam, non mecum manebit, sed nee clericus erit..." 113.

„Non dicatis uos aliquid habere proprium, sed sint uobis omnia communia. $\$ 2$. Cum huius nostrae congregationis fraitres non solum facultatibus, sed uoluntatibus propriis in ipsa ordinis susceptione renunciauerint et se per promissam obedientiam penitus aliorum potestati et inperiis in Christo et pro Christo subdiderint, certum est eos nichil habere, possuidere, dare, uel accipere sine superioris licentia debere.

§ 3. Quod si propinquus, uel amicus, uel quilibet fratrum cuiquam aliquid offere uoluerit, primo quidem priori insinuetur, et sic suscipiatur, si ipse mandauerit. De quo tamen nichil aliud fiat, nisi quod priori placuerit" 114.

„Proventus omnes ad communem usum pertineant, sive sint ex eleemosynis, sive aliunde collecti: et horum colligendorum, servandorum, dispensandonum, ea prorsus ratio quae
,Nemini igitur regularium, tam vivorum quam mulierum, liceat bona immobillia vel mobilia, cuiuscumque qualitatis fuerint, etiam quovis modo ab eis acquisita, tamquam propria

112 C. XII, q. 1, c. 9.

113 C. XII, q. 1 , c. 10.

114 C. XII, q. 1, c. 11 
Pontificius decretis continetur sub paenis ibidem contentis inviolabiter observetur. Non solum pecuniam sub privationis vocis activare et passivae poena, sed neque res comestibiles, aut potabiles quisquam apud se retineat sine Superioris facultate, idque rationabiliter ad aliquod tempus concessa. Omnes enim debent ex communi massa et mensa vivere. Haec autem facultas potissimum senibus ac aegris, tantum concedenda praeviso omni detrimento. Unde etiam mullus vestrum sine eadem Superiorum venia quidpiam a quoquam sive domestico sive externo recipiat, neque cuiquam tradat" 115. aut etiam nomine conventus possidere vel itenere, sed statim ea superioni tradantur conventuique incorporentur. Nec deinceps liceat superioribus bona stabilia allicui regulari concedere etiam ad usumfructum vel usum, administrationem aut commendam. Administratio autem bonorum monasteriorum seu conventuum ad solos officiales eorundem, ad nutum superiorum amovibiles, pertineat. Mobilium vero usum ita superiores permittant, ut eorum supellex statui paupertatis, quam professi sunt, conveniat, nihilque superflui in ea sit, mihil etiam, quod sit necessarium, eis denegetur. Quodsi quis allter quidquam tenere deprehensus aut convictus fuerit: is biennio activa et passiva voce privatus sit etiam inxta suae regulae et ordinis constitutiones puniatur" 116 .

\section{Czystość}

Najmniej uwagi, bo zaledwie kilka wierszy, Norma vitae poświęca ewangelicznej radzie czystości. O. Papczyński po:daje tylko ogólne i powszechnie znane zasady oraz wskazuje na podjęcie niezbędnych środków koniecznych do zachowania tej cnoty.

I tak Norma vitae stwierdza, że silub czystości jest ścisle związany $z$ ubóstwem i posłuszeństwem, gdyż, jak zaznacza o. Papczyński, posłuszeństwo ma za zadanie strzec czystości, a ubóstwo ją podtrzymuje. Dlatego każdy z zakonników powinien przede wszystkim i na pierwszym miejscu starać się o nabycie posłuszeństwa i ubóstwa 117 .

Wydaje się, że takie ustawienie problemu jest jak najbardziej słuszne, ponieważ lekceważenje posłuszeństwa oraz ubóstwa, po-

115 Norma vitae, III, 2.

${ }_{116}$ Concilium Tridentinum, sess. 25, decretum de regularibus et monialibus, c. 2, Conciliorum oecumenicorum decreta, jw., s. 776-777.

117 Norma vitae, III, 3. 
woduje rozluźnienie karności zakonnej, a na skutek tego bardzo często i upadek obyczałów.

Jeśli zaś chodzi o środki niezbędne do zachowania cnoty i slubu czystości to według Norma vitae są one następujące: opanowanie wzroku i wyobraźni; częsta pamięć na obeoność Bożą; unikanie bezczynności, nieużytecznych rozmów; przebywania $z$ osobami odmiennej płci; czytania niemoralnych ksiaziek; opanowanie wzroku; umiłowanie celi; szacumek dla instytucji klauzury; wzbudzanie alktów strzelistych; ustawiczne wzywanie pomocy Ducha św., Najświętszej Maryi Panny, Anioła Stróża, św. Józefa i świętych dziewic 118.

W trosce o zachowanie czystości nakazano w Norma vitae wszystkim przełożonym, by oni jako ci, na dktórych ciąży troska o podwładnych oraz odpowiedzialność wobec Boga, usilmie zabiegali o usuwanie wszelkich niebezpieczeństw mogących zagrażać tej cnocie 119.

Z tego, co powiedziano można wysnué ogólny wniosek, że zalecane przez Norma vitae środki niezbędne dla zachowania czystości w niczym nie różnią się od wskazań zamieszczonych zarówmo $\mathrm{w}$ regułach i konstytucjach zakonnych, jak i w znanych traktatach teologiczno-prawnych 120 .

\section{Praktyki pobożne}

Ćwiczenia poibożne oraz gorliwość w ich praktykowaniu, w każdym instytucie realizacji rad ewangelicznych świadczą o prężności i owocności danego instytutu. Z tego względu tak wszyscy założyciele, jak i o. Papczyńsiki, zobowiązywali zakonników do odprawiania ćwiczeń duchownych, zwanych także praktykami pobożnymi.

Spośród wszystkich ćwiczeń i̇ praktyk zakonnych Norma vitae pierwsze miejsce przyznaje ustawicznemu skupieniu, a najprawdopodobniej czyni to z powodu przynależności zakonu marianów do eremitów. Skupienie to mialo się wyrażać w stalej pamięci na obecność Bożą, Z tego względu o. Papezyński zaleca, by marianie czcili oraz kontemplowali Boga nie tylko w sobie samych, lecz również i we wszystkkich stworzeniach, gdyż ,... w nim żyjemy, poruszamy się i jesteśmy" 121.

\footnotetext{
118 Tamże.

$1: 9$ Tamże.
}

120 D. Patris Aurelii Augustini regula secunda, Codex regularum, monasticarum, canonicarum, t. II, Additamentum XXI, jw., s. 122; Tenże, Regula tertia, s. 124-125; Regula sanctorum Serapionis, Macarii, Paphnutii, et alterius Macarii, Codex regularum, t. I, s. 19-20; Regula S. Tedradio, s. 145; Regula monasterii Ferriolacensis, s. 157.

$121 \mathrm{D}: 17,28$. 
Rachunek sumienia

W życiu realizacji rad ewangellicznych ważnym środkiem, koniecznym zarówno do poznania samego siebie, jak i do postępu w świętości, jest rachunek sumienia. O. Papczyński polecił w Norma vitae, by marianie nie zaniedbywali tego ćwiczenia, ale odprawiali go codziennie $w$ czasie wyznaczonym przez przełożonych 122 .

Zgodnie z ówrzesnymi zaleceniami ascetycznymi autor Norma vitae nakazał, by w czasie odprawiania rachuniku sumienia rozmyślano nad śmiercią, miano przed oczyma czekający sąd Boży, zachęcano się do gorliwości, zdobywania zasług i oczekiwania na wieczną nagrodę 123 .

Rozmyśl an ie

Do jednej z najbardziej koniecznych i od dawna znanych praktyk w życiu zakonnym, obok rachunku sumienia, zaliczamy rozmyślanie. O znaczeniu tego ćwiczenia dia życia według rad ewangelicznych swialdczy fakt, iż według wytycznych o. Papczyńskiego na rozmyślanie należało przeznaczyć dwie godziny dziennie. Ponadto zgodnie $z$ Norma vitae $w$ kazdym domu zakonnym powinny się odbywać jednodniowe rekolekcje, od których mogli uwolnić przelożeni, ale tylko $z$ powodu uzasadnionej konieczności 124.

Odnośnie do rozmyślania o. Papczyński pisze, jż przelożeni mają czuwać, by marianie trwali w skupieniu i modlitwie za Kościól, panujących, cały zakon marianów, dołrodziejów oraz wszystikich zmarlych 125 .

Odnawianie ślubów

O. Papczyński wzorując się na dawnych regulach, konstytucjach zakonnych oraz na różnych dzielach prawnych, ascetycznych i teologiczmych zalecil, by marianie często, ale prywatnie odmawiali przed Najświętszym Sakramentem sluby zakonne. Praktyka ta 'miała na celu różnorakie zadania, jak: uświadomienie wartości powolania zakonnego i obowiązków wynikajacych $z$ profesji rad ewangelicznych oraz gotowość do walki ze zlem aż do śmierci ${ }^{126}$.

Rekolekcje

Celem ugruntowania sie $w$ powolaniu kadidy $\mathrm{z}$ nowicjuszy bezpośrednio po wstapieniu do zakonu, a inmi przed przystapieniem

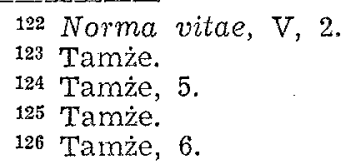


do święceń, zobowiązani byli do odprawienia dwutygodniowych rekolekcji, w czasie których pozostawali w odosobnieniu, milczeniu i skupieniu ${ }^{127}$.

Całowanie ziemi

Inną pobożną praktyką, polecaną marianom prze $z$ Norma vitae a zapożyczoną ze znanych regul i konstytucji 128, było całowanie ziemi. Według Norma vitae marianie, ilekroć przechodzili przed Najświętszym Sakramentem, tylekroć na znak adoracji realnie obecnego Boga Stworzyciela nielba i ziemi obowiązani byli do calowania ziemi 129.

Konferencje ascetyczne

Wszyscy przelożeni lokalni w każda niedzielę po wieczornym rozmyślaniu albo $\mathrm{w}$ innym czasie, powinni osobiście lub przez kogoś innego wygłaszać do swoich domowników przemówienia zwane konferencją ascetyczną. Zadaniem tej konferencji było pobudzenie do éwiczenia się $\mathrm{w}$ cnotach $\mathrm{i}$ wykorzeniania wad, oraz zachęta do postępu w doskonalości chrześcijańsikiej, zachowania karności zakonnej, wstępowania w ślady Chrystusa jak również wytrwania $w$ powołaniu zakonnym 130 .

Po zakończeniu zaś konferencji przełożony wyznaczał wszystkim na cały tydzień spełnienie jakiegoś umartwienia, iodmówienie modlitwy lub wykonanie dobrego uczynku 131. Jeśli zachodzila potrzeba, to również po konferencji, przełożony razem ze starszymi, czyli radnymi domowymi, mógl omawiać różne kwestie odnoszące się do życia codziennego 132 .

Oprócz wymienionych już praktylk pobożnych o. Papczyński zobowiązał marianów do odprawiania jeszcze innych ćwiczeń zakonnych. I tak o godzinie dwudziestej czwartej 'wszyscy udawali sie do koscioła klasztornego na adorację Najśswiętszego Sakramentu oraz w celu odmówienia oficjum ku czci Matki Bożej Niepokalanie Poczętej, które ze względu na braci konwersów nieznających laciny, recytowano po polsku, używając teikstu zaaprobowanego przez papieża Innocentego XI. Norma vitae poleciła również, by wszyscy mariande wspólnie odmawiali wszy̧stkie części brewiarza. Od tego obowiązku mógł zwolnić tylko przelożony ale pod warunkiem, że nie będzie zaniechana żadna część oficjum 133.

\footnotetext{
127 Tamże, 7.

129 Norma vitae, $\mathrm{V}, 3$.

130 Tamże, IX, 4.

131 Tamże.

132 Tamże.

133 Tamże, VI, 7.
}

128 Constitutiones religionis S. Pauli Primi Eremitae, Romae 1725, s. 64 . 
O. Papczyński polecił także i inne praktyki pobożne, jak: czytanie duchowne, odmówienie litanii do Imienia Jezus oraz codzienne uczestniczenie we Mszy siw. kkonwentualnej 134.

Przyjmowanie sakramentow i ich sprawowanie

Byłoby nie do wyloibrażenia, gdyby członkowie instytutów realizacji rad ewangelicznyoh nie przystępowali do sakramentów, a mający święcenia kapłańskie ich nie sprawowali. Naullka Kościoła katolickiego zawsze stawiała na pierwszym miejscu przede wszystkim przystępowanie do sakramentów. Stąd i Norma vitae nie mogiła postąpić inaczej.

O. Papczyński polecił, by w myśl zarządzeń dyscyplinarnych Kościoła katolickiego $\mathrm{w}$ każdą niedzielę, swięta bardziej uroczyste oraz ilekroć przełożony uzna za stosowne, zarówno kilerycy, jakk i bracia konwersi, po uprzednim odbyciu spowiedzi, ze czcią i skupieniem przystępowali do Komunil isw. Ci natomiast, którzy stale przebywali $w$ domu zakonnym, mogli przyjmować Komunię Św. raz w miesiącu 135 .

Norma vitae przewiduje również uroczyste wystawienie Najświętszego Salkramentu, tj. 'w monstrancji. Zaleca jednak, by czynić to bardzo rzadko, zachować nalleżyte uszanowanie, używać odpowiednich izzób oraz wymaganej ilości świec. Ponad'to zawsze powinien ktoś przebywać przed Najświętszym Sakramentem i modlić się 136 .

O ile nie było żadnych przeszkód, wszyscy kapłani powinni odprawiać Msze św. według intencji wyznaczonej przez przełożonego. Zgodnie zaś ze szczegółowym celem zakonu marianów mieli obowiązek odprawiać je także za dusze w czyścu cierpiące ${ }^{137}$. Każdy z kaplanów. mógl jednak raz w miesiącu odprawić dwie Misze św. wedkug własnej intencji 138 .

Norma vitae odnośnie do odprawiania Mszy św. przypomina kapłanom znane zasady, według których Mszę św. należało sprawować $w$ stanie laski, $z$ przygotowaniem, pobożnie, zgodnie $z$ przepisami Kościola, bez pośpiechu oraz bez zbytniego przedłużania 139.

Przy sprawowaniu sakramentu pokuty kapłani powinni łączyć lagodność z roztropnością. Natomiast przy rozstrzyganiu różnych problemów sumienia, a zwlaszcza ludzi prostych oraz przy wyznaczaniu pokut, winni zachować daleko posunięta ostrożność. Na ka:płanach ciążył też obowiazek znajomości grzechów zastrzeżonych zarówno Stollicy Apostolskiej, jak i Biskupom oraz przełożonym

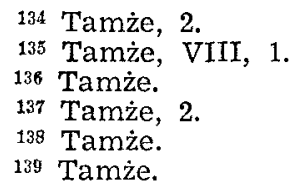


zakonnym. Kapłani winni wiedzieć, że lichwiarzom, konkubinariuszom i przywłaszczającym dobra kościelne, można było udzielić absolwcji dopiero po naprawieniu szkody tub usunięciu zgorszenia 140.

Norma vitue dia zachowania ducha pokory zaleca kapłanom sprawującym funkcje sakramentalne, by na ile to tylko będzie możliwe, osobiście sprzątali kościół, dbali o czystáśc naczyń kościelnych i paramentów oraz z racji swojej godności i z racji należnego im od wiernych szacunku, nigdy się nie wynosili ponad ludzi świeckich i nie zabiegali o zaszczyty 141.

\section{Dyscyplina zakonna}

Zarówno z historii, jak i z doświadczenia poszczególnyich instytutów realizacji rad ewangelicznych wiadomo, że od zachowania karności, czyli obserwancji, zależy rozwój i żywoltnośś życia zakonnego. Nic więc dziwnego, że każdy z zalkonodawców w swych konstytucjach zakonnych poświęci\} temu zagadnieniu sporo uwagi. Stolica Apostolska wydawała różne zarządzenia w tej materii, a w przypadku konieczności zarządzała przeprowadzenie odpowiedniej reformy.

Również o. Papczyński, autor Norma vitae, idąc za wytycznymi Stolicy Apostolskiej oraz wzorując się na pralkitykach różnych zakonów musial zająć się tą sprawą. Ponieważ zaś liczne praktyki składają się na instytucję obserwancji zalkonnej, dlatego wymagają one specjalnego omówienia.

\section{Umartwienia}

Od początku pojawienia się zorganizowanej formy życia zakonmego umartwienie zawsze uważano za jeden z zasadniczych środków dla utrzymania obserwancji zakonnej. Dlatego i Norma vitae przyznaje teij praktyce należne jej miejsce i omawia ją na wieloaspektowej płaszczyźnie. O. Papczyński zaleca nie tylko stosowamie różnyoh praktylk w dziedzinie umartwienia, lecz także zalącza szeroką motywację, ze względu na którą powinno ono być poide jmowane.

I tak w rozdziale zatytulowanym De mortificatione o. Papczynski stwierdza, że nie można $w$ żaden sposób poczynić postępów na drodze doskonałości, tj. pozbyć się starego człowieka (Adama), bez umartwienia pożądliwości, namiętności, własnej wyobraźni i woli 142. Uzasadnia to twierdzenie o. Papczyński przytaczając słowa

\footnotetext{
140 Tamże, 4.

141 Tamże.

142 Tamże, IV, 1.
} 
św. Pawła Apostoła: „Zadajcie więc śmierć temu, co jest przyziemne w (waszych) członkach" 143.

Po krótkim scharakteryzowaniu znaczenia umartwienia dia życia chrześcijańskiego $\mathrm{w}$ ogólności, a dla zaikonnego $\mathrm{w}$ szczególności, o. Papczyński zaleca marianom stoșowanie $w$ tej materii konkretnych środków. Według o. Papczyńskiego, który w tej sprawie całkowicie oparł się na nauce mistrzów życia wewnętrznego oraz na wytycznych założycieli różnych zakonów, pożywienie powinno być skromne, ale wystarczające. Jego zaś funkcja sprowadza się do zaspokojenia głodu, a nie do pobudzenia namiętności ${ }^{144}$. Dlatego positki spożywane przez marianów winny być przyrządzone $z$ jjarzyn, korzeni, ale bez różnego rodza ju wyszukanych sosów oraz innych przypraw.

Ponieważ marianie zostali zalożeni ijako eremici, $z$ tego przeto powodu zabroniono im spożywania mięsa i wyrobów z niego. Wyjątek od tej zasady uczyniono tylko dla chorych, słabych fizycznie, zakonników ibędących w podeszłym wieku oraz podróżnych ${ }^{145}$. Wolno natomiast bylo spożywać masło luib stosować do przypraw thuszcze ${ }^{146 .}$.

Co się zaś tyczy korzyśtania z napojów, to jak Norma vitae zaznacza, zakonnicy powinni używać czystej wody. Według uznania przełożonego marianie mogli jednak korzystać $z$ innych napojów, jeśli takowe mieli, lecz zawsze winni to czynić w sposób umiarkowany 147. Na szczególne zaś podkreślenie zasługuje fakt, iż o. Papczyński surowo zabronił marianom picia jakichkolwiek napojó w a k o holowych 148. Polecenie to przypomniano kilkakrotnie w ciągu historii zakonu marianów 149.

Co do ilości i jakości posilków, to w myśl ustaleń Norma vitae, mają się one składać tylko $\mathrm{z}$ dwóch skromnych dań i nigdy $\mathrm{z}$ tego powodu nie należy okazywać niezadowolenia 150. Pomimo licznych ograniczeń przełożeni, jeśli tylko uznają to za stosowne, mogą zwłaszcza w święta bardziej uroczyste oraz w czasie miesięcznej rekreacji, pozwolić na przyrządzenie posiłku $z$ więcej niż dwóch dań ${ }^{15} 1$.

Nadto o. Pappzyński zalecil, by przelożeni lagodzili, mając na

$143 \mathrm{Kol} 3,5$.

144 Norma vitae, IV, 1.

145 Tamże.

146 Tamże.

147 Tamże, 2.

148 Tamże.

149 Prot. Gosl., Cap. Gen. 1773, Puncta capitularia, f. 78 r, $108 \mathrm{r}-\mathrm{v}$, $120 \mathrm{r}, 124 \mathrm{r}$.

150 Norma vitae, IV, 2.

151 Tamże. (Marianie jako eremici zobowiązani byli do zachowania ustawicznego skupienia). 
uwadze osoby i miejsca, przepisy zamieszczone w Norma vitae dotyczące korzystania z pokarmów 152 .

W celu pobudzenia marianów $\mathrm{W}$ gorliwości do ćwiczenia się $\mathrm{W}$ umartwianiu, o. Papczyński wylicza różne szkody, które powoduje nieumiarkowanie $\mathrm{w}$ jedzeniu, jak: choroby, nieczułość sumienia etc. ${ }^{153}$.

Można się przekonać z porównania odnośnych tekstów, że podobnie jak w innych regułach, tak i według Norma vitae, nikomu nie wolno było jeść ani poza wspólnym stołem ani poza domem 154.

,Extra mensam vero nemini absque Superioris licentia quicquam sumere liceat, nec extra domum" 155 .
152 Tamże.

1.53 Tamże.

1.54 Tamże.

3.55 Tamże.

150 Constitutiones ordinis fratrum eremitarum $S$. Augustini, Codex regularum, vol. IV, jw., s. 253 .
,Nulli Fratri extra Refectorium sine speciali licentia Prioris, quae non nisi rationabili ex causa dari debet, licentia refici, et ejusmodi licentia non sit crebra" 156.

„Sed nec extra refectorium, nisi tantum in infirmitorio, esum carnium credant sibi licere, quanquam ex indulgentia possit abbas interdum aliquos fra, trum, nunc hos, nunc illos, prout necessitas postulaverit, advocare, ipsosque secum in cameria sua mielius et plenlius exhibere. Porro debiles et infir$\mathrm{mi}$, qui minutione inidigent vel aliqua medicina, non seorsum in cameris, sed omnes in infirmitorio quae necessaria fuerint sibi tam in carnibus quam in aliis recipiant competenter. Quodsi quis eorum debilis fuerit, aut etiam delicatus, ut non possit communibus cibis esse contentus, sic ei provideatur sine scandalo aliorum, ut, si abbas vel prior voluerit in refectorio misericordiam ei 
facere specialem, cibum aliquem competentem..." 157 .

\section{Posty}

Jak umartwienie, tak i post są bezwzględnie koniecznymi czynnikami ascezy chrześcijańskiej. Rozumieli to dobrze Ojcowie Kościoła, którzy kwestii tej nie skąpili należytej uwagi. A wszyscy zakonodawcy i reformatorzy życia zakonnego zagadnieniu ascezy oraz postu poświęcili dużo miejsca na kartach redagowanych przez siebie regul oraz konstytucji. Również o. Papczyński nie mógl pominąć tego problemu.

Według wskazań o. Papczyńskiego, marianie oprócz postów nałożonych wiernym przez powszechne prawo kościelne i prawo partykularne, zobowiązani zostali do powstrzymania się od spożywania pokarmów mięsnych w wigilię siedmiu świąt Matki Bożej; w uroczystość św. Michała Archanioła; św. Józefa; św. Stanisława biskupa i męczennika oraz w uroczystość św. Anny 158. Ponadto wszyscy marianie mieli obowiązek zachowania postu od 11 listopada, tj. od święita św. Marcina, az do 8 grudnia czyli do uroczystości - Niepokalanego Poczęcia oraz od zalkończenia oktarwy tegoż święta do uroczystości Boizego Narodzenia czyli do 25 grudnia. W dni postne pożywienie powinno być skromne oraz dostosowane do miejscowych zwyczajów ${ }^{159}$.

Należy zaznaczyć, że o. Papczyński przy redagowaniu wytycznych o poście, postąpił zgodnie z dyrektywami prawa powszechnego, które kazdemu zalkonodawcy oraz wladzy zakonnej pozwalalo na mprowadzenie $w$ regule oraz konstytucjach dodatkowych dni postnych ${ }^{160}$. Według zaś zarządzeń powszechnego prawa kościelnego, wszyscy zakonnicy mieli obowiązek zachowania nie tylko postu czterdziestodniowego, lecz także i innych postów nałożonych na wiernych w ciągu roku kościelnego 161.

Zasługuje równiez na podkreslenie, iz przy uzasadnianiu wartości i znaczenia postu, autor Norma vitae wykorzystał naukę Kościola

157 X. III, 35,6 .

158 Norma vitae, IV, 3.

159 Tamże.

160 F. Pel1izzarius, jw., s. 623; ,Quo iure teneantur Reguiares ad ieiunium. Teneri partim ex iure ecclesiastico communi omnibus fidelibus, partim ex consuetudine inducta fere apud omnes Religiosos, partim ex praescripto Regulae singulorum Ordinum. Ex iure quidem ecclesiastico communi ad ieiunium Quadragesimae, et alia jeiunia, quae a fidelibus per annum generaliter sumantur; ex consuetudine vero inducta ad ieiunium Adventus; ad alia denique ieiunia, quae varia custodiuntur in qualibet Religione ex praescripto Regulae: ut proinde de is sufficiens iudicium haberi non possit, nisi inspiciantur, et examinentur Constitutiones, et statuta singularum Religionum".

161 Tamże. 
stwierdzając, że celem postu oraz wstrzemięźliwości jest nie tylko umartwianie zewnętrzne, ale przede wszystkim uśmierzanie wszelkich pożądliwości 162. O. Papczyński idąc zatem za nauką Kościoła katolickiego napomina marianów, by pamiętali, iż zadaniem postu obok umartwiania ciała jest wykorzenianie wad. Dlatego, twierdzi on, iż nierozumnie postępuje taiki czlowiek, który umantwia tzw. części niższe czyli cilelesme, zaniedbuje wyższe, tj. nie wadozy z wadami 163 .

\section{Ubiór}

W czasie zakładania zakonu marianów kwestia ubioru zakonnego nie mogła stać się sprawa marginalną. Habit bowiem uważano za rzecz świętą i niezbywalną. Pieczołowicie określono jego kształt, kolor i inne właściwości. Habit stał się także znaliiem odróżniającym zakonników od duchowieństwa diecezjalnego, ogółu wiernych oraz członków jednego zakonu od członków innych zakonów 164. Dla przedlożonych wyżej racji i o. Papczyński jako zalożyciel nowego zakonu musiał zadecydować zarówno o formie, jak i o kolorze habitu.

Odnośnie habitu o. Papczyński postanowił, że marianie jako eremici, będą używali szat z płótna grubego i gorszego gatunku. Wierzchnia szata czyli habit, winna siegać do kostek a płaszcz do kolan, włosiennica miała być wykonana $z$ grubego płótna lub $z$ innego ostrego materialu.

Zarówno kolor habitu, jak i płaszcza dia uczezenia Najjświętszej Maryi Panny, powinny być koloru białego. O. Papczyński wprowadzając różne zarządzenia dotyczące stroju zalecił, by każdy z marianów troszczył się o czystość szat, gdyż jak zaznaczył, niedbałość $w$ tej materii ani nilkomu się nie podoba ani téz nie świadczy o duchu ubóstwa 165 .

O. Papczyński wydając zarządzenia o habicie i ubiorze zakonników nie pominął i innych szczególów odnoszących się do zewnętrznego wyglącu, np.: obuwia, peleryn welnianych, tonsury i strzyżenia włosów.

Postanowił on, by w lecie i tyllko wewnątrz domów zakonnych marianie używali sandałów zrobionych $z$ drzewa, natomiast ' $w$ zimie, a zwlaszcza w okolicach o niskich temperaturach, ze względu na

${ }_{362}$ Tamże: „... quod Ecclesia per ieiunium intendit, ut corpora fidelium castigentur, et concupiscentia coerctatur; non autem ut natura laedatur notabiliter...".

163 Norma vitae, IV, 3.

${ }_{104} \mathrm{~J} . \mathrm{K}$ a ło w sk i, Dzialalność zakonodawcza księdza Józefa Turczynowicza, Warszawa 1982, s. 62-64.

165 Norma vitae, IV, 4. 
zachowanie zdrowia, obuwie powinno być proste, jednolite, tj. jednakowe dila wszystkich, a jednocześnie skromne czyli odpowiadające duchowi ubóstwa 166. W zimie zaś, ale za zgodą przelożonego generalnego, mogli marianie używać welmianych peleryn oraz skórzanej czapiki. Natomias't bracia praculjący czyli ci, którzy nie odmawiali $\mathrm{w}$ chórze razem $\mathrm{z}$ pozostalymi ani modlitw za zmarlych, ani oficjum po łacinie, mieli nosić habit dlugi, ale koloru szarego, a nie bialego oraz pelerynę, lecz bez kołnierza ${ }^{167}$. Wszyscy zarówno duchowni jak i bracia konwersi obowiązani byli do noszenia tonsury, której wielkość uzależniona została od szczegółowych przepisów wydanych dla zakonów czyli była to tzw. tonsura św. Piotra. Każdego zaśs miesiąca mieli obowiązek golenia zarówno brody, jak í wąsów 168 .

\section{Skupienie $i$ milczenie}

Jak potwierdza historia bardzo ważnym czynnikiem koniəcznym do zachowania obserwancji zakonnej, jest insitytucja skupienia i milczenia. Nie ma przeto ani konstytucji, ani regul, ani innych aktów prawnych reformujących życie zakonne, które by nie stawialy na naczelnym miejscu tego zagadnienia. Nic więc dzi winego, że o. Papczyński poleca ustawiczne skkupienie, które ma polegać na stałej pamięci o obecności Bożej oraz na kontemplacji Boga we wszystkich stworzeniach, a nie tylko w nas samych 169 . Co się zaś tyczy milczenia, to ponieważ, jak twierdzi o. Papczyniski, stoi ono na straży skupienia, $z$ tej przeto racji należy je zachowywać wszędzie i zawsze, a szczególnie $w$ itakich miejscach jak: kapllicy, zakrystii, refektarzu oraz w innych pomieszczeniach zarezerwowanych dla czlonków wspólnoty zakonnej ${ }^{170}$.

Norma vitae mówiąc o obowiązku oraz o znaczeniu milczenia, określa również czasokres, w którym wyklucza się jalkąkolwiek rozmowę. Takie ścisłe milczenie obowiązywało od błogosławieństwa wieczornego aż do rannego. Chodziło tu prawdopodobnie o blogosławienśstwo, którego udzielal przelożony na zakończenie modlitw wieczornych i przed rozpoczęciem pacierzy porannych 171 . Przepis ten dopuszczal jednak pewne wyjątki. Można było zatem przerwać milczenie ścisłe tylko w przypadku konieczności, ale i wówczas, ma ile czas na to pozwalał, należało uprzednio uzyškać pozwolenie przelożonego ${ }^{172}$.

\footnotetext{
166 Tamże, 5.

167 Tamże.

168 Tamże.

169 Tamże, V, 1.

170 Tamże, 4.

171 Tamże.

172 Tamże.
} 
Podobnie jak $\mathrm{w}$ innych zakonach, tak również i $\mathrm{w}$ zakonie marianów milezenie obowiązywało także w czasie trwania wszystkich posilków, podczas których czytano Pismo św., szczególnie Nowego Testamentu, życiorysy świętych, regułę zakonu czyli Norma vitae lub inne książki, ale wyłącznie o treści religijnej, a zwłaszcza takie, które traktowały o doskonałości chrześcijańskiej 173.

Pisząc o obowiązku zachowania miliczenia o. Papczyński przypomina marianom jeszcze jedną ważną zasadę, w myśl której przed podjęciem rozmowy $z$ bislkupem lub przełożonym należało poprosić ich o błogosławieństwo na znak szacunku i dla uczczenia w nich osoby Chrystusa 174.

Kończąc omawianie obowiązku odnoszącego się do zachowania milczenia i skupienia zalecanego ow pierwszym akicie prawnym marianów można zakonkludować, ḋ̇ zarówno instyitucja milezenia, jak i skupienia, była praktyką powszechnie znaną oraz stosowaną $\mathrm{w}$ codziennym życiu zakonnym 175. Dlatego o. Papczyński nie wniósł $w$ tej sprawie ani nic nowego ani niekoniecznie musiał się wzorować na konstytucjach pijarów ${ }^{176}$.

\section{Studium}

Inną praktyką mającą na celu pogłębienie wiedzy teologicznej było czytanie dzieł sławnych autorów - moradistów, lub zapoznanie się $z$ rubrykami do mszału rzymskiego napisanych przez kitóregoś $z$ tzw. auctores probati. Za jednego $z$ takich autorów odpis Norma vitae, sporządzony w Portugaliii i tam dotychczas przechowywany, uważa Bartolomeo Gavanti ı(+1638) 177.

Po zakończeniu kolacji odbywało się też czytanie jakiegọś dzieła traktują̨cego o życiu zakonnym lub, podobnie jak i w innych zaikonach, prowadzono dyskusję zmierzającą do wyświetlenia zagadnień dotyczących spraw sumienia, zwanych pospolicie casus conscientiae 178. O tym, ize praktyka taka znana była $\mathrm{w}$ innych zakonach można się przekonać z zestawienia itekstów Norma vitae $z$ innymi źródłami.

173 Tamże, VI, 2.

174 Tamże, V, 4.

17:5 Reguta św. Ajugustyna, Starożytne reguly zakonne, jw., s. 101; Porkariusz - Napomnienia ascetyczne, s. 105; Regula Pawła i Stefana, s .154; Regula św. Kolumbana, s. 243; Regula św. Benedykta, jw., c. VI, s. 24.

${ }_{176}$ Constitutiones Congregationis Pauperum Dei Scholarum Piarum, 1758 , p. II, s. 7 , n. 1 .

177 Norma vitae, VI, 3.

178 Tamże, 5.

10 - Prawo Kanoniczne 
„Septima conferetis vos ad refectorium collationem cum lectione sumpturi; qua finita in communi sedentes, vel de religiosa perfectione, promovendaque gloria Dei, vel de casibus conscientiae invicem conferetis modeste et non iactabunde" 179 .
"Lectio Sacrae Scripturae, vel casuum conscientiae bis in hebdomada, praescriptis diebus in singulis Conventibus habeatur, ad quam Fratres omnes conveniant; eaque absoluta, mutua collatione circa explicatam doctrinam sese utilliter exerceant" 180 .

Ponadito, podobnie jak i inne zakony również marianie, zobowiązani byli do ustawicznego zapoznawania się (czytania) z dokumentami Stollicy Apostolskiej. Przelożonym zaś nie tyllko surowo zabroniono interpretacji dekretów wydanych przez majwyższą władzę kościelną, ale nakazano im, by je mprowadzali w życie. Przelożeni natomiast, którzy by je komentowali lub nie chcieliby ich zachowywać, zaciągali następujące kary przewiddziane wo tych dekretach: pozbawienie zaijmowanych urzędów oraz pozbawienie na stałe zdolności do sprawowamia jakichkolwiek olbowiazzków 181.

Przytoczone wyżej rozporządzenia zamieszczone w Norma vitae, zobowiązujące marianów do czytania dekre'tów Stolicy Apostolskiej, zapożyczono, jak na to wskazuje poniższe zestawienie odnośnych teksstów, $\mathrm{z}$ dekrebu Klemensa VIII Nullus omnino z dnia 25 VII 1599 r., wydanego dila zakonu serwitów 182.

„Summorum Pontificum decreta praescripto tempore amnino legantur ad mensam: nec putent Superiores sibi fas esse ea intempretari, sed cum omni possibilitate serventur, et paenae in iis contentae in transgressores extendantur" ${ }^{183}$.
„Superioribus autem, nec Concilii Tridentini, aut haec nostra decreta declarare, interpretari, aut relaxare ullo modo possint, omnino interdicimus, et prohibemus. Decernentes irritum, etc., si quis autem contha praesumpserit attentare, is eo ipso omni gradu, officioque privatus, et ad ea perpetuo inhabillis existat" 184.

O. Papczyński polecił także, by marianie studiowali Pismo św. i teologie moralną, trwall na ustawicznej modilitwie araz nieskazitelnością życia i ćwiczeniem się w pobożności nie tylko rozsła-

\footnotetext{
179 Tamże.

1800 C 1 e mens VIII, decr. Nullus ompinio, 25 iul, 1599; Fontes I, 11. $187, \S 1$.

181 Tamże, $\S 8$.

182 Tamże.

183 Norma vitae, VI, 6.

184 Clemens VII, decr. Nullus ommino, $\$ 8$, jw.
} 
wiali, podtrzymywali i przyczyniali sie do rozrostu zakonu, lecz by wspierali także cały Kościół katolicki 185.

\section{Klauzura}

Od początku pojawienia się w Kościele zorganizowanej formy życia zakonnego klauzura była instytucją nie tylko zalecaną, ale zawsze uważano ją za konieczny warunek chroniący osoby zakonne od wpływu czynników zewnętrznych ${ }^{186}$. $Z$ tego zatem powodu wszyscy, na których spoczywała odipowiedzialność za utrzymanie kkarności zakonnej, wydawali liczne i szczegółowe zarządzenia oraz dokładnie określali miejsca objęte zakazem wstępu do domu zakonnego czyli klauzurą ${ }^{187}$.

W zredagowanym dla marianów akcie ustawodawezym Norma vitae, również i o. Papczyński podal ogólne, przewidziane przez prawo powszechne zasady odnoszące się do instytucji kilauzury 188.

Według przeto wytycznych Norma vitae wejście do domu zakonnego powinno być zawsze zamiknięte na dklucz. Również bez pozwolenia przełożonego, nikogo z osób obcych nie wolno było wipro"wadzać do pomieszczeń zarezerwowanych dla zakonników.

Podobnie i zakonnicy mogli wychodzić pioza oibręb klasztoru jedynie w przypadku konieczności, za wiedzą i zgodą przełożonego oraz, o ile szczególne okoliczności nie uzasadnialy zastosowania jakiegoś wyjątku, zawsze $z$ socjuszem. Nie stosującym się do powyższego przepisu przelożony, stosownie do wielkości wykroczenia, mógł wymmierzyć odpowiednią karę 189.

Zakkonnicy zaś przebywając poza klauzurą obowiązani byli do dawania dobrego przykładu, zachowania obserwancji zakonnej oraz do odprawiania, o ile mic nie stał̆o na przeszkodzie, ćwiczeń zakonnych 190. Natomiast po każdorazowym powrocie do klasztoru każdy zobowiązany był do zdania przelożonemu sprawozdania ze wszystbkich czynności załatwianych poza klauzurą 191.

Ponieważ klauzurę uważano za jeden ze środków ułatwiających skupienie, diatego przepisy odnoszące się do niej rozciągano nie tylko na wychodzemie poza klasztor, ale stosowano ją również do wychodzenia i wchodzenia do pomieszczen znajdujących się we-

185 Norma vitae, VIII, 2.

188 Instrukcja Kongregacji do Spraw Zakonników i Instytutów Swieckich ,Venite seorsum", 15 VIII 1969, AAS 61 (1969) 674-690; F. B ogda n, Geneza $i$ rozwój klauzury zakonnej, Poznań 1954; J. L e c l e r c q, F. Cubelli, E. Ancilli, R. Hostie, Clausura, Dizionario degli istituti di perfiezione, t. II, Roma 1979, kol. 1166-1183.

187 Tamże.

188 Norma vitae, $\mathrm{V}, 8,9$.

189 Tamże, 8.

190 Tamże.

191 Tamże. 
wnątrz klasztoru, a zwłaszcza do pokoi. Dla zachowania więc ciszy i skupienia bez uzasadnionego powodu nikt nie mógł ani wychodzić ze swego pakoju ani tym bardziej wchodzić do celi innego zakonnika 192. Również od momentu dania sygnału do udania się na nocny spoczynek nikt nie powinien, a to ze względu na zachowanie ciszy i karności zakonnej, chodzić po korytarzu, na którym według. rozporządzeń papieskich miała się świecić lampka ${ }^{193}$.

O. Papczyński podkreślając zarówno ważność, jak i znaczenie klauzury dla rozwoju życia zalkonnego polecił umiłowanie celi, Uktóra symbolizowala miejsce tylko doczesnego zatrzymania się w niej 194. Z tej racji każdy winien osobiście sprzątać pokój, posiadać w nim wodę święconą, obraz Matki Bożej i świętego patrona. Dla zachowania jednak ubóstwa obrazy powinny być wykonane $z$ papieru, a nie malowane na płótnie 195. Bez uprzedniego. zaś pozwolenia przełożonego nikomu, poza czasem wyznaczonym, nie wolno było spać ${ }^{196}$.

\section{Kapituła win}

Jedną ze znanych i powszechnie stosowanych instytucji, mających na celu zadośćuczynienie za popelnione wylkroczenia oraz dla uniknięcia ich w przyszłości, była tzw. kapituła win. Polegała ona na tym, iż wszyscy zakonnicy gromadzili się 'w sali, zwanej kxapitularzem i tam kazdy $z$ osobna wobec wspólnoty i przełożonego oskarżał się z zewnętrznych wykroczeń, po czym otrzymywał odpowiednie mapomnienie oraz poikutę. Chociar praktyka odlbywania kapituły win była instytucją obowiązującą wszystkie za«xony ścisłe, to jednaik nie było określonego siposobu ani co do jej zwolywania ani co do jej odprawiania. Każdy więc zakon mógł posługiwać się swoimi własnymi wytycznymi 197.

Podobną praktykę wprowadzil o. Papczyński, zobowiązując przelożonych, by w każdy piątek we wszystkich domach mariańskich odbywała się kapituła win, podczas której przelożony w zależności od wiellkości i szkodliwości wykroczenia wyznaczał każdemu odpowiednią pokutę 198. Norma vitae zaleca również, by nikt nie usprawiedliwiał się $z$ popelnionych zewnętrznych wylkroczeń, lecz by $z$ uległością i miłością przyjął nałożoną mu karę. Gdyby na-

\footnotetext{
192 Tamże, 9.

193 Tamże, 8.

194 Tamże, 9.

195 Tamże.

190 Tamże.

197 E. D'A s c oli, I c. della colpa, Enciclopedia cattolica, t. III, Cittá del Vaticano 1949, kol. 691; G. Ghis l a in, Capitolo delle colpe, Dizionario degli istituti di perfezione, vol. II, jw., kol. 176-179.

198 Norma vitae, IX, 3.
} 
tomiast $\mathrm{w}$ czasie odbywania kapituly win zaszedł taki przypadek, iż fałszywie kogoś posądzono o popełnienie wykroczenia, które nie miało miejsca, to niesłusznie abwiniony nie powinien się usprawiedliwiać, lecz w stosownym czasie przedstawić przełożonemu racje przemawiające na ikorzyść swojej niewinności 199.

O. Papczyński pisząc o kapitule win uwzględmił także przepisy prawa powszechnego, według których na wszystkich fałszywych oskarżycieli należało nałożyć odpowiednią karę odwetową 200. Najprawdopodobniej chodzilo tu o kary przewidziane przez prawo dekretałów przeciwko oszczercom oraz przeciwlko tym, którzy dostarczadi władzy informacji o przestępstwie, które nigdy nie mialo miejsca 201.

Ponieważ podczas odlbywania kapituły win, zwanej także trybunałem miłości, mogły zaistnieć mieprzewidziane scysje, dlatego o. Papczyński zaleca, by ich unikać i nie kierować się przesadną gorliwością, nie interesować się zbytnio wadami współbraci oraz, - ile nie zachodzi uzasadniona konieczność, wystrzegać się wyjawiania wylkroczen popełnianych przez innych 202.

\section{Biczowanie}

Prakityka biczowania obowiązująca wówczas we wszystkich zakonach, stanowiła jeden ze środików zalbezpieczaljących zachowanie i utrzymanie karności zakonnej 203. Według zatem nauki o. Papczyniskiego wspólne biczowanie powinno się odlbywać trzy razy $w$ tygodniu, $t \mathrm{tj}$. w poniedziałek, środę i piątek, a jego zasadniczym celem, oprócz zachowania i rozwoju dyscypliny zakonnej było wynagrodzenie za grzechy własne i innych oraz za dusze w czyścu ciempiące.

Oprócz ibiczowania wspólnego Norma vitae zaleciła także, by w miarę możliwości, każdy $\mathrm{z}$ marianów uprawiał to ćwriczenie prywatnie albo przed udaniem się na spoczynek albo na polecenie przelożonego $w$ innym czasie 204 .

Należy także dodać, iż Norma vitae w trosce o rozwój karności zakonnej, zarządziła stosowanie innego środka, a mianowioie polecono, by marianie spali na sienniku wypełnionym shomą oraz

199 Tamże.

200 Tamże.

$201 \mathrm{X} . \mathrm{V}, 2,1-2$.

202 Norma vitae, IX, 3; Mt 18, 15-17.

203 Por. Constitutiones Coelestinorum, Codex regularum, monasteriorum et canonicarum, t. IV, jw., s. 535; Constitutiones Congregationis Pauperum Dei Scholarum Piarum, jw., p. II, s. 4, n. 10.

204 Norma vitae, IV, 6. Chodzi o umartwienia i biczowania dodatkowe, których nie można bylo praktykować bez pozwolenia przełożonego. 
okrywali się tylko własnym plaszczem lub jalkimś wełnianym okryciem 205.

\section{Organizacja i zarząd}

Zarówno ongamizacjili, jalk i zarządowi, kstóry stanowi c on diti o sine qua non każdego instytutu realizacji rad ewangelicznych, Norma vitae poświęca rozdział siódmy i część rodziału dziewiątego. Ponieważ zagadnienie organizacji i zarządu obejmuje wiele elementów, dlatego każdemu $\mathrm{z}$ nich należy poświęcić nieco uwagi.

\section{Ustanawianie przelożonych}

Norma vitae żąda, by ci, którzy są wybierani na urząd przelożonych odznaczali się: obserwancją zalkonną, posłuszeństwem, wiernością natchnieniom Ducha Swiętego, pobożnością, roztropnością, zachowaniem tajemnicy urzędowej oraz łączeniem łagodności z surowością ${ }^{206}$. Oprócz wymienionych przymiotów, przelożeni powinni również posiadać $\mathrm{k}$ walifikacje wymagane przez prawo powszechne.

Ponadto o. Papczyński domagal się także, by przełożeni nie obciążali swoich podwładnych nadmiernymi pracami, lecz by uwzględniali przy wyznaczaniu obowiązków zarówno kwalifilkacje, jak i uzdolnienia poszczególnych zalkonników ${ }^{207}$.

Podwładni natomiast, nawet $\mathrm{w}$ przypadku gdyby przełożeni nie wywiązywali się ze swoich zadań, winni ich otaczać miłością, szacunkiem, unikać względem nich zuchwałości, a zarządzenia wykonywać nie z bojaźni, lecz z uległości 208.

O. Papczyński mówiąc o stosunku podwładnych do przełożonych zaznacza, że częsito są oni godni współczucia, gdy służąc innym zmuszeni są zapomnieć o sobie. Dlatego, pisze o. Papczyński, mając na względzie dobro całego zakonu, należy się modlić za przełożonych, by Bóg ich oświecał, kierowal nimi, wspomagał ich oraz obdarzał swoją łaską 209.

O tym, że wytyczne Norma vitae dotyczące przymiotów i sposobu sprawowania władzy przez przełożonych całkowicie pokrywały się $\mathrm{z}$ wymaganiami prawa powszechngo, można się przekonać $\mathrm{z}$ zestawienia tekstów Norma vitae $\mathrm{z}$ innymi kościelnymi aktami prawnymi.

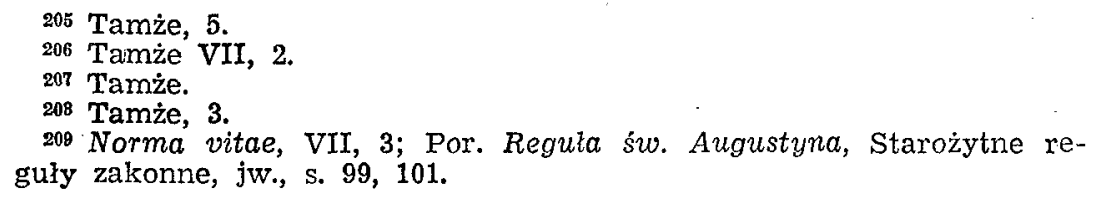


„Quiliibet aurtem Superiorum meminerint illius Divini Spiritus moniti... Rectorem te posuerunt? noli extolli, esto in illis, quasi unus ex ipsis. Quare non dominator, sed forma gregis effectus, prius faciat exemplo, quod imperaturus est verbo, pariter cum omnibus legum servator, non tantum custos, pietate, discretione, prudentia praeditus, zelum lenitate, lenitatem zelo attemperans; ne per nimium rigorem, aut conniventiam magis obsit Instituto, quam prosit. Non aggravet suos rigidis paenitenti'is, aut mandatis; conformia viribus, talentis, qualitatibus, cuique imponens. Cum enim teneanitur subditi sine excusatione parere, providendum est imperanti, ut talia iniungant, quibus cum gloria Dei, et suo merito, quisque satisfacere possit" 210 .
"Seniores ergo qui in voibis sunt obsearo consenior et testis Christi passionum, qui et eius quae in futuro revelanda est gloriae communicator: pascite qui est in volbis gregem Dei, providentes non coacto, sed spontanee secundum Deum: neque turpis lucri gratia, sed voluntarie: neque ut dominantes in cleris, sed formae facti gregi ex animo" 211. „Cum praecepto divino mandatum sit omnibus, quibus animarum cura commissa est, oves suas agnoscere, pro his sacrificium offerre, verbique divini praedicatione, sacramentorum administratione ac bonorum omnium operum exemplo pasicere, pauperum alliamumque miserabilium personarum curam paternam gerere et in cetera munia pastoralia incumbere, quae omnia nequaquam ab his praestari et impleri possunt, quil gregi suo non invigilant neque assistunt, sed mercenarium more deserumit: sacrosancta synodus eos admonet et hortatur, ut divinorum praecepitonum memores, factique forma gregis, in iudicio et veritae pascant et regant" 212 .

„Eadem sancta Tridentina synodus... nonnulla statuere... quo facilinus et commordius sibi subiectos regere et in vitae ac morum homestate continere potuerint, -illud primum eos admonendos censet; ut se pasto-

210 Norma vitae, VII, 2.

Li1 1 P 5, $51-4$.

212 Concilium Tridentinum, sess. XXIII, Decreta super reformatione, canon 1, Conciliorum oecumenicorum decreta, jw., s. 744 . 
res, non percussores esse meminerint, atque ita praeesse sibi subditis oportere, ut non in eis dominentur, sed illos tanquam filios ot fratres diliganit..." 213 .

Ponieważ organizacja zakonu marianów była centralna czyli władzę sprawowali przełożeni różnych podporządkowanych sobie stopni, o Papczyński opierając się na wytycznych kościelnego prawa powszechnego, zadanie wyiboru przelożonych wyższych powierzył instytucji zwanej kapitułą.

W zakonie marianów kadencja przełożonych była czasowa ${ }^{214}$. Dlatego w celu dokonania wyboru przełożonych, co sześć lat odbywała się kapitula generalna 215. Do zaidan tej kapituły nalaża między innymi: wybór przełożonych wyższych, asystentów czyli radnych generalnych, prokuratora generalneigo etc. ${ }^{216}$. Miejscem kapituły generalnej była $z$ zasady siedziba ustępującego przelożonego generalnego 217. Norma vitae przewidywala również różne czynności wistępne poprzedzające formalne rozpoczęcie kaupituly. Najpierw więc wyborcy czyli uczestnicy kapituły powinni przez jeden dzień pościć oraz odprawić śpiewaną Mszę 'św. o Duchu Swiętym. W celu zaś szyblkiego dokonania wyborów, wyborcy dotąd mieli przebywać w odosolonieniu, dopóki w tajnym glosowaniu nie wybrali nowego przełożonego. Każdy záś $z$ elektorów zobowiązany lbył do wybrania tego spośród kandydatów, kstóry posiadał wymagane przymioty czyli odznaczał się świętością, roztropnością, nieskazitelnością życia, obserwancją zakonną oraz wiedzą ${ }^{218}$.

Norma vitae poleciła, by podczas wyborów zachowano wszystikie formalności przewidziane przez prawo powszechne 219. A zatem mając na uwadze rozporządzenie prawa powszechnego, zwrócono uwage, by ci, kitórzy by w czasie wyborów kierowali się stronniczością, zostali na zawsze pozbawieni głosu czynnego i biernego 220 .

${ }^{213}$ Concilium Tridentinum, sess. XIII, Decretum super reformatione, Conciliorum oecumenicorum decreta, jw., s. 698; Por. D. LXXXVI, 2.

214 Norma vitae, VII, 1.

215 Tamże, IX, 1.

216 Tamże.

217 Por. S. M. S y dry, Organizacja zgromadzenia księży marianów,

Stockbridge 1965, s. 103.

218 Norma vitae, IX, 1.

219 Tamże.

220 Tamże. 


\section{Obowiazki przetożonych}

Z urzędem przelożonych łączą się liczne obowiązki, gdyż przeworinicząc wspólnotom zakonnym winni się oni troszczyć o właściwą realizację celów życia zakonnego. I tak na podstawie wielu zarządzeń jedną $z$ ważnych powinności przełożonych było przeprowadzenie wizytacji. Podobnie i Norma vitae zarządziła, by przelożony generalny wizy'owal iwszystkie domy zakonne co trzy lata, przełożony diecezjalny czyli prowincjalny raz w roku, a przełożony miejscowy dla przekonania się, czy nie zakradły się jakieś nadużycia luib czy rzeczy będące $\mathrm{w}$ posiadaniu przez zakonników odpowiadają duchowi ubóstwa, wimien co miesiąc sprawdzić wszystkie pomieszczenia zajmowane przez członków wspólnoty 221.

Innym obowiązkiem przełożonych była troska o zakonne dobra doczesne. Jako administratorzy dóbr, winni oni baczyć, by nie ulegly one zniszczeniu oraz marnotrastiwu.

O. Papczyński zarząiził, by przełożeni pod żadnym pozorem oraz pod karami przewidzianymi 'w prawie kościelnym, nie alienowall dóbr zakonnych ${ }^{222}$. Wzorowal się on na oibowiązującym wówczas prawie kościelnym, jak można się przekonać z zestawienia przepisu Norma vitae z odnośnymi tekstami prawa powszechnego.

"Quae ipsis nullo modo a Congregatione alienare sub Ecclesiasticis paenis, licebit" 223 .
„Quisquis episcopus uel abbas de salariis episcopi uel monasterii quicquam transferre in principium manus, uel etiam alii personae conferre uoluerit, irritum sitt quod datum esse constiterit, secundum canonem sanctorum Apostolorum, qui dicit: „omnium ecclesiasticarum rerum episcopus habeat sollicitudinem, et dispenset eas tamquam Deo contemplante. Non liceat autem ei fraudare quicquam ex illis, uel cognatis propriis donare que Dei sunt. Quod si pauperes fuerint, ut pauperibus largiatur, sed non sub horum occasione que sunt ecclesiae defraudentur".

221 Tamie, VII, 4.

222 Norma vitae, VII, 4; Por. C. XII, q. 2, c. 19; X. III, 13, 1; Clem. III, 4, 1; Extravag. Com. IIT, 4 nn. 223 Norma vitae, VII, 4. 
$\S 1$. Qund si excusationem pretenderit episcopus dampnum fam cere et nichil ad profectum agrum existere, nec sic principibus tribuatur ager uel locus, sed clericis uel agricultoribuis.

§ 2. Quod si calliditate usus fuerit princeps, et uel a colono uel a clero agrum emerit, sit irrita uenditio, et restituatur episcopio et monasterio. Episcopus uel abbas hoc faciens abiciatur, tamquam qui dispersit que non collegit" 224. ,Non licet episcopo vel abbati terram unius ecclesiae vertere ad alliam, quamvis ambae in eius sint potestate; tamen, si commutare voluerit terras earum, cum consensu ambarum partium faciat" 225.

"Nulli liceat alienare rem immobilem ecclesiae suae, sive domum sive agrum, sive hortum sive rusticum mancipium (vel panes civiles) meque creditoribus specialis hypothecae titulo obligare. Allienationis autem verbum continet conditionem, idonationem, venditionem, permutationem et emphyteusis perpetuum contractum. Unde amnes (omnino) sacerdotes ab huiusmodi alienatione abstineant, poenas timentes, quas Leonina constituitio comminatur" 226 .

Ponieważ, stwierdza Norma vitae, w kościolach zakonu mariarianów powwinny być wyglaszane kazania, dlatego dla sprostania temu zadaniu oraz w celu osiągnięcia więisszych skutków przez wiernych, przełożony generalny zolbowiązany był wy:znaczyć spe-

224 C. XII, q. 2, c. 19; Por. C. XII, q. 2, c. $20,23$.

$225 \mathrm{X}$. III, 13, 1; Por. X. III, 13, 6-8.

226 X. III, 13, 5; Por. X. III, 13, 6-8. 
cjalnych kapłanów, zwanych kaznodziejami. KKapłani ci, kontynuuje Norma vitae, winni się adznaczać wiedzą teologiczną oraz osobistą świętóścią 227. Na kaznodziejach ciążyła powinność gloszenia prawdziwej nauki Kościoła katolickiego oraz tylko tego, co przyczyniało się do szerzenia chwały Bożej, poprawy wiernych, wzrostu milości, szacunku względem Boga, praktykowania cnót, dobrych uczyników, pogardy dla rzeczy doczesnych oraz pragnienia osiągnięcia życia wiecznego 228.

Uwzględniając wymagania prawa kościelnego o. Papczyński podecił wszystkim kapłanom $z$ zalkonu marianów, by we własnym kościele nie głosili tkazań bez wiedzy i zgody przelożonego, a w innych kościołach bez wiedzy i zgody miejscowego ordynariusza miejsca 229 .

Do uprawnień przysługujących przełożonemu generalnemu należało też wyznaczanie wykkładowców zwanych lektorami, wyższych seminariów duchownych. Lektorzy ci mieli za zadanie przekazywanie klerykom wiedzy filozoficznej i teologicznej 230 . Norma vitae poleca, by $w$ nauczaniu lektorzy korzystali $z$ podręczników autorów cieszą̧cych się wielkim autorytetem w Kościele. Lektorzy winni pamiętać, że $\mathrm{w}$ formacji alumnów na maczelnym miejscu nalleży stawiać sprawy nadprzyrodzone i nigdy nie wolno przenosić nauki mad modlitwe lub umartwienie 231.

Ponieważ na mocy pozwolenia papieża Innocentego XI, udzielonego dnia 20 III 1681 r., oraz za wiedzą ordynariusza miejsca, przy każdym kościele zarządzanym przez zakon marianów mogły być erygowane bractwa Niepokalanego Poczęcia, dlatego do zadań przełożonego należało wyznaczenie odpowiedniego promotora. Promotor zaś mial się usilnie starać, by ci, którzy odznaczają się gorliwością $\mathrm{w}$ modlitwie za dusze w czyścu cierpiące, wpisywali się na listę członków bractwa Niepokalanego Poczęcia. Nadto $w$ zakres obowiązków promotora wchodziło zachęcanie członków owego bractwa do ơllbywania częstej sporwiedzi, przystępowania do Komunii św., praiktykowania dzieł miłosierdzia oraz wykorzeniania własnych wad 232.

Oprócz wyżej wymienionych obowiązków do uprawnień przełożonego generalnego należało: mianowanie i usuwanie spowiedników, mistrzów nowicjatu, cenzorów książek religijnych, przełożonych lokalnych, ekonomów, prokuratorów, przyjmowanie nowych fundacji, troska o rozwój kultu Bożego we własnych kościołach zakonnych, zachowanie ladu i spokoju w klasztorach, zachowanie

\footnotetext{
227 Norma vitae, VII, 5.

228 Tamże.

229 Tamże.

230 Tamże, 6.

231 Tamże.

232 Tamże, 8.
} 
skupienia, miłości, zgody, zapobieganie wylkroczeniom, karanie występnych, wydawanie własnych ustaw, oraz wprowadzanie $\mathrm{w}$ życie ustaw Kościoła powszechnego ${ }^{233}$.

Konkludując można twierdzić, iż nałożone przez Norma vitae na przełożonych obowiązki w niczym nie różniły się od wymagań przewidzianych zarówno przez prawo powszechne, jak i przez reguły poszczególnych zakonów.

\section{Przyjęcie do zakonu, formacja i usuwanie}

Odnośnie do przyjęcia do zakonu marianów, formacji oraz wydalania Norma vitae nie wprowadziła żadnych dodatkowych przepisów, lecz jak wynika $z$ ogólnych sformułowań zamieszczonych $\mathrm{w}$ omawianym dokumencie, $\mathrm{w}$ całości przyjęla ona $\mathrm{w}$ tej materii obowiązujące wówczas wytyczne prawa kościelnego.

Przede wszysttkim, pisze autor Norma vitae, kandydaci do zakonu marianów powinni być dobrze znani, albo przynajmniej polecani przez osoby godne zaufania 234 . Kandydaci do zakonu mieli obowiązek przedłożenia świadectwa potwierdzającego ich prawe pochodzenie ${ }^{235}$. Ponadto na kandydatach ciążyła powinność wykazania, że pragną prowadzić życie świętsze niż inni wierni, że swoje postępowanie dostosowują do zadań zakonu oraz że usilnie i wytrwale reallizować będą cel swego powołania 236 .

Przelożeni zaś zobowiązani byli również do zbadania czy aspiranci nüe są obłożeni cenzurami, czy mie mają obowiązkku spłacania długów oraz czy nie są zamieszani $w$ spory, $z$ powodu których mogłyby im grozić jakieś procesy sądowe 237 .

Konkludując można wysunąć twierdzenie, że zarówno wedlug Norma vitae, jak $i$ według prawa powszechnego, do zakonu marianów mógı być przyjąty każdy katolik, wolny od przeszkód kanonicznych, kierujący się prawą intencją oraz zdolny do ponoszenia ciężarów życia zaik.onnego 238 .

Co się zaś tyczy przygotowania czyli formacji kandydatów do życia zakonnego Norma vitae funkcje te zlecala magistrowi (mistrzowi) nowicjatu, którego każdorazowo powolywał i odwoływal

233 Tamże, 9.

234 Norma vitae, I, 4; $\mathrm{Sixtus} \mathrm{V}$, const. Cum de omnibus, 26 nov. 1587, \& 4-5, Fontes, I, n. 162.

235 Tamże.

236 Tamże.

237 Tamże.

238 Por. C. $\mathrm{XX}$, q. 2 , c. 2 ; X. III. 31, 1 ; $\mathrm{Sixtus} \mathrm{V}$, const. Cum de omnibus, jw.; Clemens VIII, const. Cum ad regularem, 19 mart. 1603, \& 5, Fontes, I, n. 189; A l ex a n d er VII, const. Sacrosancti, 18 ian. 1658, Fontes; I, n. 235; Cle men s IX, const. In excelsa, 13 sept. $1669, \S 1$, Fontes, I, n. 244; S.C.C., decr. 21 sept. 1624, \& 1, Fontes, V, n. 2454 . 
przełożony generalny. Norma vitae poleca, by na urząd ten wyznaczano kapłanów przykładnych, roztropnych, pracowitych, abdarzonych zdolnością rozeznawania duchów (spirituum discretione praeiditii) oraz talkich, którzy uczyliby nowvicjuiszy wyrzekania się samych siebie, naśladowania Chrystusa, pogardy dla dóbr doczesnych, umiłowania dóbr wiecznych, cierpliwości, pokory, skromności, skikupienia, pokuty, rumilowania modlitwy, zachowania karnosici zakonnej, a szczególnie milości Boga 239.

Norma vitae napomina również mistrzów nowicjatu, by zawsze ożywiała ich myśl, ìz zlecone im obowiązki mają przede wszystkim zmierzać do zbawienia duszy nowicjuszy oraz do urobienia kzandydatów na doibrych zakonników 240 .

Według Norma vitae także i w formacji kandydatów należało w całej rozciągłości podporządkować się zarządzeniom Stolicy Apostolskiej. Zatem nikogo nie można było dopuszczać do składania ślubów, o ile nie istniała pewność o zdatności kandydatów. Zdatność ta przejawiała się w zamilowaniu do modlitwy, umartwieniu, skupieniu oraz $\mathrm{w}$ praktykowaniu innych cnót 241.

Również i do święceń kapłańskich, przełożeni, pod ciężką odpowiedzialnością $\mathrm{w}$ sumieniu, mogli dopuścić tylko takich czlonków, którzy ukończyli wymagane przez prawo studia (seminarium) oraz odznaczali się stałością charakteru czyli byli utwierdzeni w cnocie $\mathbf{2 4 2}$.

Wiadomo $z$ ogólnych zasad prawa kościelnego, że do otrzymania święceń konieczny był tytuł kanoniczny. Najbardziej znanymi tytułami do święceń dla duchowieństwa diecezjalnego są: titulus ecclesiae oraz titulus servitii dioecesi, zaś dla duchowieństwa instytultów realizacji rad ewangelicznych tytulami takimi są: titulus paupertatis, titulus mensae communis oraz inne 243. Według zaś wytycznych Norma vitae bezwzględnie ksoniecznym tytułem do otrzymania i udzielenia święceń był tytuł ubóstwa (titulus paupertatis). Norma vitae wymaga także innych, jakby uzupełniających tyłtułów, takich jak: przyczynienie się do wzrostu kultu Bożego wśród członków zakonu marianów oraz modlitwa za dusze w czyścu cierpiące 244 . Wymienione przez Norma vitae tytuly dodatiowe do święceń powinno się jednalk uważać raczej za przymioty, którymi winni się odznaczać kandydaci do kapłaństwa.

Jak wyżej zaznaczono, Norma vitae we wszystkim co dotyczylo

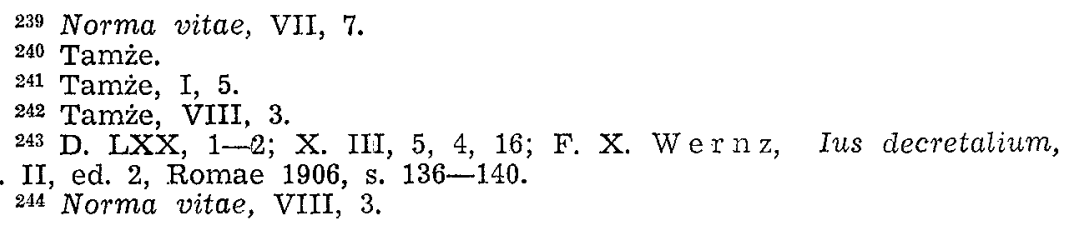


formacji polecila, by stosować się do konstytucji papieskich $\mathbf{2 4 5}$. Konstytucji zaś papieskich w sprawie formacji w nowicjacie było wiele 246. Jedne $z$ nich Stollica Apostolska wydala dla wszystkich instytutów realizacji rad ewangelicznych, inne natomiast mialy. zasięg tyllko terytorialny, tj. obowiązywały niektóre instytuty 247.

Jednym $z$ najbardziej znanych i powszechnie obowiązującym dokumentem traktującym ex professo o' nowicjacie i formacji, była konstytucja papieża Klemensa VIII Cum ad regularem $\mathrm{z} 19$ III 1603 r. ${ }^{248}$. Dolkument ten $\mathrm{w}$ sposób szczegółowy rozstrzygnął wiele kontrowersyjnych problemów związanych z nowicjatem i formacją $w$ nowicjacie. O znaczeniu tego akitu dia instytucji nowicjatu może świadczyć fakt, iż Kodeks Prawa Kanonicznego z 1917 r. prawie w calości przejąl zawarte w nim wytyczne 249 .

Inną ważną sprawą, lecz poruszoną tyllko zdawkowo przez 10. Papczyńskiego w Norma vitae była kwestia opuszczenia instytutu marianów. O. Papczyński pisze, iż ci, kitórzy złożyli śluby powinni trwać w zakonie i dlatego nie wolno im będzie samowolnie porzucić stanu zakonnego 250. Norma vitae, wzorująic się na powszechnym prawie kościelnym, pozwala jedynie ma przejście do innego zakonu, ale o ściślejszej obserwancji. I w tym przypadku jednak mogło to nastąpić tyluko za zgoda przełożonych oraz za dyspensą Stolicy Appositolskiej 251. Tego rodzaju procedura znana byla w prawie juz od końca wieku dziewiątego, a została ona zapoczątkowana na synodzie triburieńskim w 895 r252. Piszą równiez - tym wszyscy kiomentatorzy prawa dekretałów 253.

Norma vitae wzorując sie calkowicie na prawie dekretałów, podaje także środiki zaradcze, które powinni przedsięwziąć przelo-

245 Tamże, I, 5.

246 Por. Piu s V, const. Et si mendicantium, 16 maii 1567, Fontes, I, n. 121; S ixtus V, const. Cum de omnibar, jw.; Sixtu S V, const. Ad Romanum, 21 oct. 1588, Fontes, I, n. 170; Gregorius XIV, const. Circumspecta, 15 mart. 1591, Fontes, I, n. 170; Cle me n s VIII, const. Cum ad regularem, jw.

247 Tamże.

248 Fontes, I, n. 189.

249 Por. Kan. 558-565.

250 Norma vitae, I, 5.

251 Tamże.

252 C. XX, q. 4, c. 1, da: ,Quod uero ab uno monasterio in aliud districtius transire monachis liberum sit, ex Concilio Triburiensi habetur, in quo sic statutum est: Virgines sacrae si pro lucro animae suae propter districtiorem uitam ad aliud monasterium pergere disposuerint, ibidernque conmanere decreuerint, sinodus concedit. Si uero fuga disciplinae alium locum quesierint, redire cogantur". dp: „Quod autem de uirginibus sacris hoc capitulo statuitur de monachis etiam consequenter intelligitur, de quolibet etiam clerico".

${ }_{253}$ P. F a g nanus, jw. s. 356-357, 392-395; V. P ichler, Ius canonicum practice explicatum lib. III, Ingolstadt 1721, s. 926-927. 
żeni $\mathrm{w}$ odniesieniu do zakonmików niepoprawnych, to znaczy takich członków, którzy nie stosują się do dyscypliny zakonnej, spiskują przeciwko władzy oraz są powodem zgorszenia dla innych. Takich zakonników kompetentne wladze zakonne powinny najpierw trzykrotnie upomnieć, a $\mathrm{w}$ razie braku poprawy osadzić na sześć miesięcy $w$ karcerze, a gdyby i to nie odniosło pożądanego skutku, można było przystąpić do zastosowania sankcji ostatecznej, polegającej na wydaleniu z zakonu 254.

\section{Zatwierdzenie „Norma vitae"}

Każdy instytut realizacji rad ewangelicznych musi posiadać jakiśs stopień zatwierdzenia ze strony prawowitej władzy kościelnej. Zatwierdzenie takije jest konieczne dlatego, gdyż instytuty życia wedlug rad ewangelicznych są osobami prawnymi. A według prawa kościelnego wszystikie osoby moralne powinny być erygowane, a zatem i aprobowane. -

Powstaje przeto pytanie czy i normy prawne, którymi kieruja sie nowoerygowane osoby moralne, a w naszym przypadku instytuty zakonne, musialy być także aprobowane? I czy prawo kościelne pozwalało na założenie zalkonu bez równoczesnego zatwierdzenia konstytucji?

Zanim jednak odpowiemy na te pytania, wcześniej należy zaznaczyć, że w.prawdzie, jak o itym dowiadujemy się z napisu zamieszczonego ma odpisie egzemplarza Norma vitae, przechowywanego $w$ Archiwum Diecezjalnym w Lublinie, na wniosek Kongregacji Bisiksupów i Zalkonników, Norma vitae zostala przejrzana i poprawiona przez kardynała Lucjusza Colleredo, to jednak doikument ten nigdy nie uzyskał zatwierdzenia władzy kościelnej. Fakt niezatwierdzenia Norma vitae, pomimo usilnych starań o. Papczyńskiego oraz innych marulanów, należy tłumaczyć órwczesnymi przzepisami prawmymi i prakktyka Stolicy Apostolskiej. W czasie bowiem zakładania zakonu marianów, jak świadczą znawcy prawa zalkonnego, nie spoitykamy się z żadnym przepisem, który by czy to bezpośrednio czy pośrednio domagal się apostolskiego zatwierdzenia konstytucji 255 .

Arkadiusz Larraona, znany i powszechnie ceniony ekspert $w$ sprawach zakikonnych, kardynal i prefekt Kongregacji do Spraw Zakonnych, odnośnie do apostolskiego zatwierdzenia konstytucji ipisze: „Ex regula generali adhuc necessarium non est, ut constitutiones a S. Sede probentur, et non plures, sed quidem aliquae, inveniuntur constitutiones a S. Sede non approbatae" 256 .

254 Norma vitae, I, 5.

255 L. R. R a va si, jw., s. 37.

256 A. Larra ona, Commentarium Codicis, Commentarius pro religiosis 4 (1923) 137. 
Ponadto istniała praktylka, zgodnie z którą Stolica Apostolska nie przystępowała do zatwierdzenia konstytucji, przed aprobowaniem instytutu 257 . Zatwierdzenie ksonstyltucji przed zaaprobowaniem zakonu zawsze uważano za wyjątek 258.

Pomimo tego, że konstytucje zakonne niekoniecznie musiały być zatwierdzone to jednak, chociaż mie zawsze, obowiązywała inna prakityka. Mianowicie na mocy zarządzenia Soboru Lateraneńskiego IV z 1215 r. nowe zakony wolno było zakładać tyllko w oparciu o juź zatwierdzone i uznane reguly zakonne 259 . Dlatego w historii instytutów zakonnych spotykamy się z przypadkami, iż przyjęcie jednej $z$ uznanych regul było koniecznym warunkiem do urzędowego zatwierdzenia instytutu zakonnego. Dla przykładu można wymienić bonifratrów i somasków, których zatwierdzono w oparciu o regułę sw. Augustyma 260.

O takim postępowaniu Stolicy Apostolskiej zdaje się itakże świadczyć zdarzenie jakie miało miejsce w czasie podejmorwania starań o apostolskie zatwierdzenie zakonu marianów. Stolica Apostolska jeszcze przed przystapieniem do rozpatrywania próśb marianów zażądała, by za podstawę swego życia zakonnego przyjęli oni jedna $z$ zatwierdzonych regul zakonnych 261 .

\section{Zakończenie}

$\mathrm{Z}$ omówienia Norma vitae wynika, iż dokument ten stanowi nie tylko pierwszy akt ustawodawczy dla zakonu marianów, ale jest on również jednym z pierwszych i dotychczas wcale nieznanych konstytucji zalkonnych ułożonych przez Polaka, o. Stanisława Papczyńskiego dla pierwszego rdzennie polskiego zakonu męskiego założonego na naszych ziemiach $\mathrm{w}$ siedemnastym wieku. Zatem 0 . Papczyńskiego można uznać za pioniera działalności zakonodawczej w Polsce. Genialność o. Papczyńskiego przy zakladaniu marianów polegała na właściwym odczytaniu przez niego znaków czasu i potrzeb chwilli, co rprzejawiało się $\mathrm{w}$ konieczności modlitwy za dusze $w$ czyścu cierpiące, szczególnym kulcie Niepokalanego Poczęcia Najświętszej Maryi Panny oraz pomocy proboszczom w pracy duszpasterskiej.

Należy położyć szczególny nacisk na to, że oryginalność myśli

257 L. R. Ravasi, jw., s. 40.

258 Tamże.

259 X. III, 36, 9; J. P. M ü 11 e r, J. Torres, Documenti pontifici di approvazione, Dizionario degli istituti di perfezione, vol. III, jw., kol. $751-777$.

260 J. P. Müller, J. T orres, jw., kol. 767-768.

261 Problem przyjęcia przez marianów jednej z regul zatwierdzonych przez Stolice Apostolską oraz kwestia jurysdykcyjnej zależności marianów od zakonu braci mniejszych zostanie omówiona w najbliższym numerze kwartalnika „Prawo Kanoniczne”. 
zakonodawczej o. Papczyńskiego uwidoczniła się w Norma vitae i w tym, iz surowo zabronil on członkom zakonu marianów spozywania alkoholu pod jakąkolwiek postacią. Zamieszczeni.e tego przepisu w Norma vitae, uwzglęniwszy ówczesną sytuacją Polsiki, a szczególnie duze spożycie mapojów alkoholowych przez wszy stlkie warstwy społeczeństwa, było decyzją nie tydko odważną, lecz także pelną troski o dobro przyszłych piokoleń narodu.

W aritykule wylkazano nadto, iż o. Papczyński znal dobrze zarówno ówczesne prawo zakonne i kościelne, jak i inne kwestie odnoszące sie do życia zakonnego, gdyż wszystkie przepisy zamieszczone w Norma vitae mają swoje źródło w prawie dekretałów.

W opracowaniu zwrócono uwage na zależności Norma vitae od aktów ustawodawczych Stolicy Apostolskiej oraz różnych regul i konstytucji zakonnych. W celu zaś dokładniejszego uwidocznienia zgodności przepisów Norma vitae z innymi wcześniejszymi aktami ustawodawczymi odnośne teksty zestawiono obok siebie w dwóch kolumnach.

Przy wykazywaniu wspomnianych zależności starano się w miarę możliwości nie tyllko dotrzeć do najstarszych źródel, lecz usiłowano wykazać, diz pewne instytucje zakonne opisywane przez 0. Papczyńskiego w Norma vitae, były powszechnie znane i stosowane we wszystkich zakonach ścisłych.

Należy również zaznaczyć, że w Norma vitae 0 . Papczyński dobrze połączył życie czynne z kontemplacyjnym. Polecił on mianowicie marianom, jak wskazuje na to rozkład porządku dziennego, odprawianie wielu ćwiczeń zakonnych, ale lkazał im też zajmować się duszpasterstwem czyli pomagać proboszczom w pracy duszpasterskiej. Jednak pomoc proboszczom zlecil nie wszystkim marianom, ale tylko tym, którzy odznaczali się odpowiednimi przymiotami.

W opracowaniu wykazano, że o. Papczyński poruszył w Norma vitae wszystikie istotne zagadnienia dotyczące życia zaikonnego. A jeśli nawet pewnym kwestiom poświęcil mało uwagi, to i wówczas kazal calkowicie zastosować się do wytycznych prawa powszechnego.

\section{De „Norma vitae" seu de primis ordinis Marianorum constitutionibus}

In articulo hoc auctor diligenti subiecit analysi atque explicavit nondum notas constitutiones a Polono, P. Stanislao Papczyńs'ki, secunda parte dimidia saeculi septimi decimi confectas easque Marianorum ordini impositas qui primus in Polonia ordo religiosus exstitisse noscitur.

Qua in quaestione recte et ordine diiudicanda auctor praefatione instructus in ,Norma vitae" data, item praescriptis canonicis saeculi decimi septimi necnon eiusdem temporis canonistarum operibus innixus indolem et naturam iuridicam ordinis Marianorum demonstrat multisque argumentis probat $P$. Papczyński institutum stricte eremi-

11 - Prawo Kanoniczne 
ticum neque condidisse neque condendum sibi proposuisse, sed in ordine religiosorum condendo congruenter cum praescriptis egisse iuris canonici universalis hisce temporibus vigentis. Auctor enarravit eiusdem ordinis propositum principale necnon particulare atque media explicavit, quibus Mariani adiuti imposita eis ab eorum conditore $P$. Papczyński officia et munia rite obire possint.

Item enarratur, quo modo Marianorum vita consiliis evangelicis accommodanda sit atque demonstratur omnia "Normae vitae" iussa ad vota spectantia a religiosis viris emittenda cum iuris canonici praescriptis concordare, immo nonnulla eorum ex variis Sedis Apostolicae decretis necnon religiosorum tunc exsistentium constitutionibus et regulis ad verbum deprompta esse.

Item auctor breviter animum advertit ad pias exercitationes describendas, sine quibus vita religiosa nequidem mente concipi possit.

Deinde modo omnino singulari problema disciplinae religiosae disceptatur, quae multis defensitatur praescriptis in "Norma vitae" contentis.

Denique ipsa compositio et constitutio Marianorum ordinis enarratur atque eiusdem regimen explicatur necnon praescripta interpretantur cum quaestione hac connexa, ut superiorum electio corumque animi dotes atque obligationes. Quaestionibus autem de sodalibus in ordinem recipiendis necnon de eorundem formatione religiosa atque de religiosis ex ordine removendis tota disputatio clauditur.

Quia autem primae Marianorum constitutiones, quas diximus, sive iuridica sive historica eorum ratione habita scientifice elaboratae non sunt, articulo hoc non minimi momenti lacuna impletur in Polonorum litteratura canonistica usque ad tempus nostrum existens. 